\title{
Development of the rhopalial nervous system in Aurelia sp.1 (Cnidaria, Scyphozoa)
}

\author{
Nagayasu Nakanishi • Volker Hartenstein • \\ David K. Jacobs
}

Received: 28 January 2009 /Accepted: 27 May 2009 /Published online: 20 June 2009

C) The Author(s) 2009. This article is published with open access at Springerlink.com

\begin{abstract}
We examined the development of the nervous system in the rhopalium, a medusa-specific sensory structure, in Aurelia sp.1 (Cnidaria, Scyphozoa) using confocal microscopy. The rhopalial nervous system appears primarily ectodermal and contains neurons immunoreactive to antibodies against tyrosinated tubulin, taurine, GLWamide, and FMRFamide. The rhopalial nervous system develops in an ordered manner: the presumptive gravitysensing organ, consisting of the lithocyst and the touch plate, differentiates first; the "marginal center," which controls swimming activity, second; and finally, the ocelli, the presumptive photoreceptors. At least seven bilaterally arranged neuronal clusters consisting of sensory and ganglion cells and their neuronal processes became evident in the rhopalium during metamorphosis to the medusa stage. Our analysis provides an anatomical framework for
\end{abstract}

Communicated by M.Q. Martindale

Electronic supplementary material The online version of this article (doi:10.1007/s00427-009-0291-y) contains supplementary material, which is available to authorized users.

N. Nakanishi $\cdot$ D. K. Jacobs $(\bowtie)$

Department of Ecology and Evolutionary Biology, UCLA,

621 Young Drive South,

Los Angeles, CA 90095-1606, USA

e-mail: djacobs@ucla.edu

V. Hartenstein

Department of Molecular, Cellular and Developmental Biology,

UCLA,

621 Young Drive South,

Los Angeles, CA 90095-1606, USA

N. Nakanishi $(\bowtie)$

Sars International Centre for Marine Molecular Biology,

Thormøhlensgt. 55,

5008 Bergen, Norway

e-mail: nagayasu.nakanishi@sars.uib.no future gene expression and experimental studies of development and functions of scyphozoan rhopalia.

Keywords Cnidaria · Scyphozoa - Rhopalia .

Nervous system development $\cdot$ Medusa

\section{Introduction}

Sensory structures, defined as distinct multicellular parts of an organism that function to perceive sensory stimuli, are ubiquitous in Metazoa. Examples range from morphologically highly complex-lensed eyes of vertebrates, cephalopods, and cubozoan medusae to a morphologically simple but functionally sophisticated feeding chamber of sponges [see Jacobs et al. (2007) for further description of sponge sensory structures]. We know much about the development of sensory organs in a few bilaterian model organisms (e.g., Drosophila and Mus), but our knowledge of sensory structure development in non-model organisms, especially the non-bilaterian metazoans, has advanced relatively little. For instance, although gravity-sensing organs and eyes can be found in cnidarian medusae (Horridge 1969; Martin 2002), the developmental pathway by which these structures are generated remains largely unexplored [but see Kozmik et al. (2003), Bebenek et al. (2004), and Stierwald et al. (2004) for recent developmental genetic efforts]. Detailed knowledge of sensory structure development from a diverse array of metazoan species is indispensable for better understanding of the evolution of senses in Metazoa. In this paper, we examined the development of cnidarian sensory structures, rhopalia, in the scyphozoan jellyfish Aurelia.

Phylogenetically, cnidarians are the likely sister group to bilaterians (Medina et al. 2001; Wallberg et al. 2004; but see Schierwater et al. 2009 for a contrary view) and consist 
of two sister clades, anthozoans (e.g., corals and sea anemones) and medusozoans (e.g., jellyfishes) (Collins 2002). Medusozoans include staurozoans, hydrozoans, cubozoans, and scyphozoans. Cnidarians have ectoderm and endoderm separated by extracellular matrix, the mesoglea (Brusca and Brusca 2003). Typically, cnidarian zygotes develop into motile planula larvae, which metamorphose into polyps after settlement onto appropriate substrates. In most medusozoans, polyps undergo another round of metamorphosis to generate free-swimming sexual medusae, while polyps sexually mature as adults in anthozoans, staurozoans and some derived hydrozoans (e.g., Hydra). Metamorphosis of a scyphozoan polyp (Fig. 1a) generally entails a process known as strobilation, by which a single polyp (now called strobila) undergoes transverse fission to generate one or more larval medusae referred to as ephyrae (Fig. 1b, c). Monodisk strobilation produces a single ephyra per strobila, while polydisk strobilation generates up to 30 ephyrae. In the polydisk strobila consisting of a stack of ephyrae as in Aurelia (Fig. 1b), development and subsequent release of individual ephyrae occurs sequentially from the oral pole down toward the aboral pole so that ephyrae in upper (i.e., oral) positions in the strobila are normally more developed than those below. The basal portion regenerates tentacles and an oral disc to remain as a polyp. Each free-swimming ephyra develops into an adult medusa.

Rhopalia are club-shaped bodies located around the bell margin in medusae of scyphozoans and cubozoans, with the number typically in multiples of four (Fig. 1c-g; Hyman 1940). The structure of scyphozoan rhopalia has been previously examined in adult Aurelia medusae. Each rhopalium has a "lithocyst" (also referred to as a "statocyst" in cnidarian literature) at the terminal end (lc in Fig. 1e-g), consisting of endodermal, crystalline-statolith-containing lithocytes, covered by a thin ectodermal epithelium (Hyman 1940). On the oral side near the lithocyst is a mass of subepidermal ectodermal sensory cells with their apical cell surface facing a cup-shaped single layer of endodermal pigment cells, together called the "pigment-cup ocellus" (co in Fig. 1e-g; Hyman 1940; Yamasu and Yoshida 1973). In the ectoderm on the aboral side, there is a "pigment-spot ocellus" (so in Fig. 1g) just proximal to the lithocyst, formed by a patch of epidermal pigment cells (Hyman 1940; Yamasu and Yoshida 1973), and a "touch plate" located proximal to the pigment-spot ocellus (tp in Fig. 1g), consisting of a thickened field of epidermal sensory cells (Chapman and James 1973; Hundgen and Biela 1982). The pigment cells of the spot ocellus synapse with the underlying nerve net (Yamasu and Yoshida 1973), suggest-
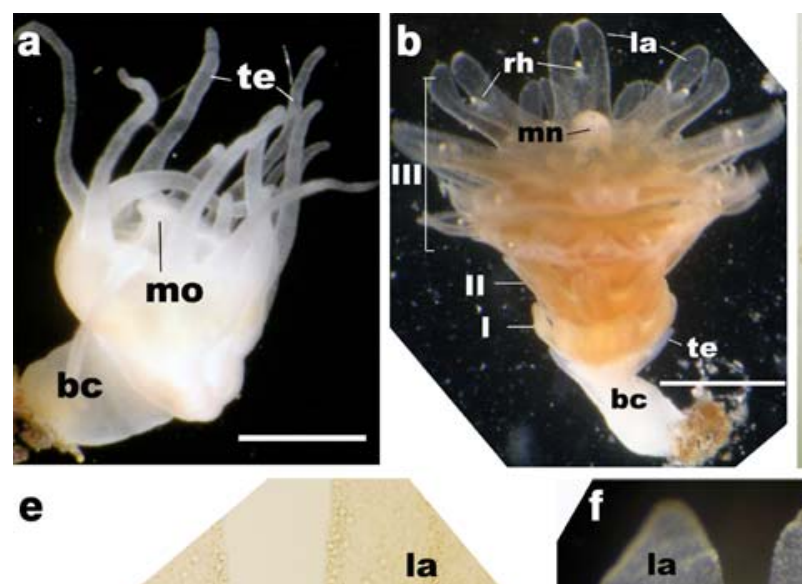

Ia

la

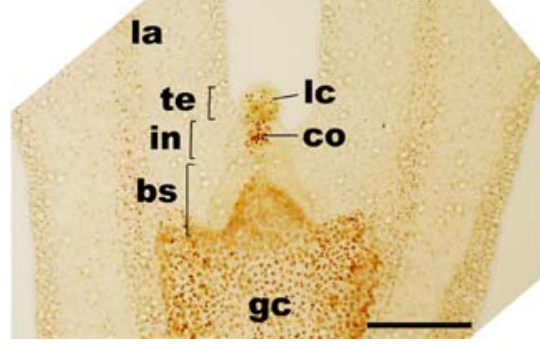

Fig. 1 Development of a medusa from a polyp and the structure of the rhopalium in Aurelia sp. 1 a Polyp. b Strobila. c Ephyra (oral view). d Metephyra (oral view). e Enlarged view of a rhopalium in $\mathbf{c} . \mathbf{f}$ Enlarged view of a rhopalium in $\mathbf{d}$. $\mathbf{g}$ Lateral view of a rhopalium of a metephyra. te tentacle, mo mouth, $b c$ body column, $r h$ rhopalium, $l a$ lappet, I prephyra I stage (see text), II prephyra II stage, III prephyra
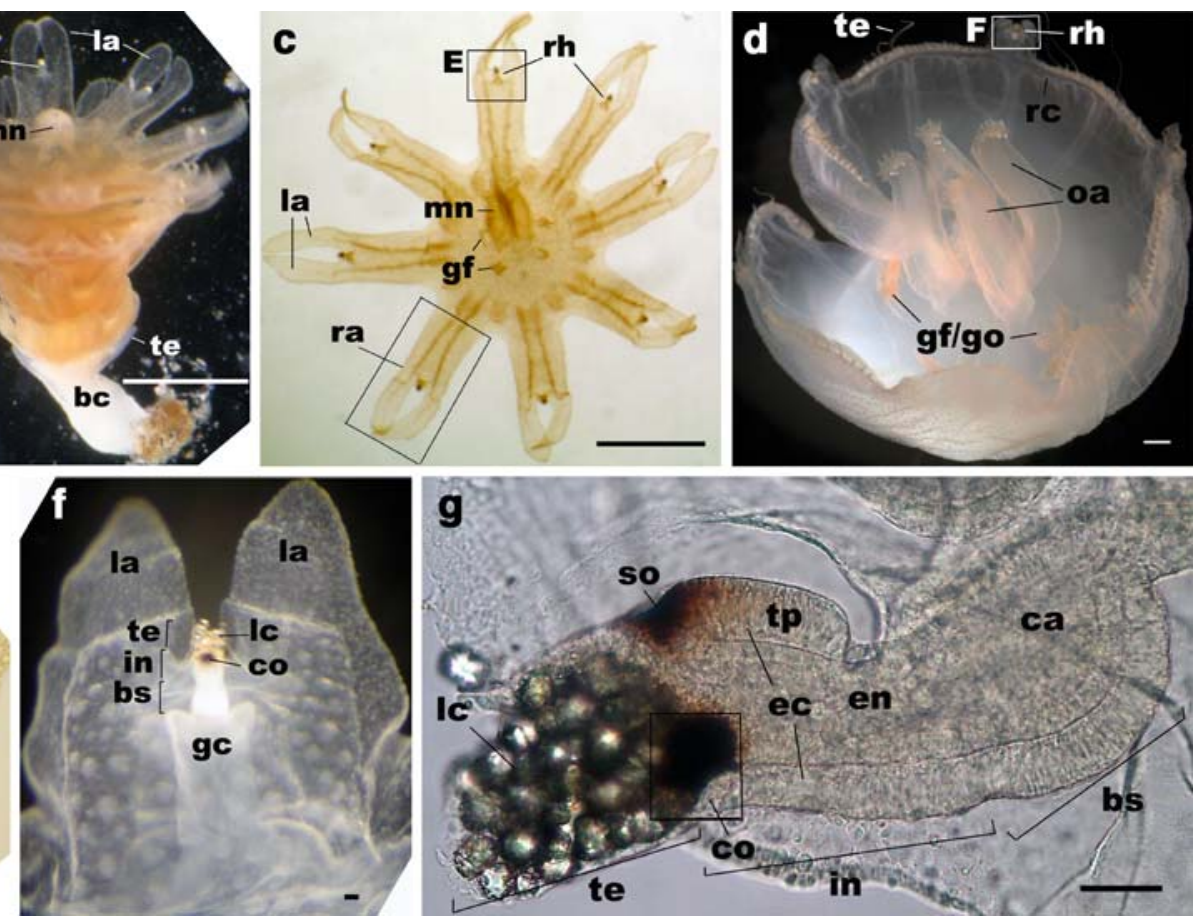

III stage, $m n$ manubrium, $r a$ rhopalar arm, $g f$ gastric flaments, $g f / g o$ gastric filaments/gonads, oa oral arm, $r c$ ring canal, $l c$ lithocyst, $c o$ pigment-cup ocellus, so pigment-spot ocellus, $t p$ touch plate, $g c$ gastrovascular cavity, $c a$ rhopalar canal, ec ectoderm, en endoderm, te terminal segment, in intermediate segment, $b s$ basal segment 
ing that these pigment cells are themselves neurons. It is often assumed that the lithocyst and the touch plate together function to sense gravity in scyphozoan rhopalia (Arai 1997; Spangenberg et al. 1996; Chapman and James 1973; Hundgen and Biela 1982). When the medusa is tilted, gravity pulls the heavy lithocyst, bending the body of the rhopalium, so that cilia on the sensory cells in the touch plate would make contact with or be removed away from the overlying epithelium (called the "hood" in adult). The resulting mechanical stimuli then presumably trigger the gravity-sensitive behavior such as righting. The righting behavior occurs via asymmetric contraction of the swimming muscle that acts to restore the balance against the gravitational force (Bozler 1926; Frankel 1925; Horridge 1956b; Passano 1982). Indeed, ablation experiments have shown that the lithocyst (in the uppermost position in the medusa upon tilting) is necessary for righting in scyphozoan medusae (Bozler 1926; Frankel 1925), suggesting the importance of the lithocyst for gravity-sensing function of the rhopalium. In addition, the rate of swimming contraction increases upon illumination in adult Aurelia medusae, but this photic behavior is abolished when the pigment-cup ocelli are removed (Horstmann 1934), indicating that the pigment-cup ocellus on the oral side (co in Fig. 1e-g) is photosensory. The function of the pigment-spot ocellus on the aboral side (so in Fig. 1g) remains unclear but may not be photosensory (see Discussion).

Previous studies have indicated that the nervous system of scyphozoan medusae contains two physiologically and anatomically distinct nerve nets that meet and interact at rhopalia (Horridge 1956a; Passano 1965; Romanes 1877). Swimming behaviors involving periodic contractions of subumbrellar muscles are elicited by electrical impulses that are conducted via the motor nerve net $(\mathrm{MNN})$ or the giant fiber nerve net (GFNN) (Horridge 1954, 1956a; Romanes 1885). The MNN consists mostly of large bipolar ganglion cells that reside at the base of swimming muscle epitheliomuscular cells in the subumbrellar (i.e., oral) epithelium, innervating the closely associated swimming muscle fibers (Anderson and Schwab 1981; Horridge 1956a; Passano 1965; Schwab and Anderson 1980). Another conducting system, called the diffuse nerve net (DNN), includes all non-rhopalial sensory cells and their thin neuronal processes, and this nerve net transmits sensory information to a "marginal center" in the rhopalium to modulate its activity (Horridge 1956a; Passano 1965). The marginal center refers to the pacemaker of the rhopalial nervous system that generates a regular electrical impulse into the MNN to cause swimming contractions, but its anatomical location is unknown (Passano 1982; see Discussion). Horridge (1956a) showed histologically that the DNN and MNN neurons were connected to neurons in the rhopalium.

Some aspects of the temporal pattern of rhopalial nervous system development in Aurelia can be inferred based on data from previous publications. At the onset of strobilation before rhopalia begin their formation, swelling occurs at the bases of perradial and interradial tentacles ${ }^{1}$ in the transforming polyp, which are the sites of rhopalial development (Spangenberg and Kuenning 1976). At these locations, cilia with the characteristic size (8$12 \mu \mathrm{m})$ of ephyra-type presumptive mechanoreceptor cells as well as statoliths have been observed (Spangenberg 1976; Spangenberg 1991). Tentacles degenerate, and the margins become lobed to form arms, which are, in this paper, referred to as "rhopalar arms" (ra in Fig. 1c) in order to distinguish them from the "oral arms" that develop in the manubrium (oa in Fig. 1d). At the distal end of the developing arm, feeding appendages known as "lappets" begin to form, which flank each of the developing rhopalia (la in Fig. 1b, c; Spangenberg and Kuenning 1976). Rhopalia and lappets of ephyrae below the uppermost segment develop from the body column (Russell 1970). Regular spontaneous contractions begin in developing ephyrae before they detach from the strobila, and electrical impulses from the rhopalia show direct correspondence with each contraction, suggesting that the $\mathrm{MNN}$, the marginal center, and swimming musculature develop in the strobila (Schwab 1977). Differentiation of sensory cells of the pigment-cup ocellus has been observed in a 1-dayold, free-swimming ephyra, and a somewhat later development of the pigment-spot ocellus was inferred (Yamasu and Yoshida 1973; Yoshida and Yoshino 1980). An "organized" touch plate has been observed in a 2-day-old freeswimming ephyra (Spangenberg et al. 1996). These observations suggest that the presumptive gravity-sensing organ of the rhopalium, consisting of the lithocyst and the touch plate, may begin development first, followed by the marginal center, and finally the ocelli.

However, comprehensive data on the neuroanatomy of developing rhopalia have not been available so that direct support of the above-described developmental succession is lacking. We examined the nervous system development in rhopalia from the strobila through the late ephyra in Aurelia sp.1 (sensu Dawson and Jacobs 2001), using immunohistochemistry and confocal microscopy. We show that development of the rhopalial nervous system occurs in an ordered manner concordant with the proposed developmental succession. In addition, the results indicate that the rhopalial nervous system has a bilaterally symmetrical organization consisting of morphologically and molecularly

\footnotetext{
${ }^{1}$ The mouth of the scyphozoan polyp and medusa is cross-shaped when closed and viewed from the oral side, and planes along each line of the cross are termed perradii. The planes that bisect perradial planes are termed interradii, and the planes halfway between the perradial and interradial planes are termed adradii. Thus, in a polyp with 16 tentacles, there are four perradial, four interradial, and eight adradial tentacles.
} 
distinct populations of ectodermal sensory and ganglion cells with their neuronal processes forming complex basiepithelial networks. Our work presents the most comprehensive information to date on the anatomy and development of the nervous system in scyphozoan rhopalia and provides a framework for future gene expression and experimental studies of development and functions of scyphozoan rhopalia.

\section{Materials and methods}

\section{Animals}

Polyps, strobilae, and ephyrae of Aurelia sp.1 (sensu Dawson and Jacobs 2001) were obtained from the Cabrillo aquarium (San Pedro, CA, USA). In the laboratory at UCLA (Los Angeles, CA, USA), they were kept in circulating natural seawater at $16^{\circ} \mathrm{C}$ and were fed 2-dayold Artemia (Ocean Star International Inc.) at least twice a week.

\section{Fixation of animals}

Aurelia sp.1 strobilae and ephyrae were anesthetized in 7.3\% $\mathrm{MgCl}_{2}$ for $15-30 \mathrm{~min}$. All specimens were fixed in $4 \%$ formaldehyde for $1 \mathrm{~h}$ at room temperature $\left(20-25^{\circ} \mathrm{C}\right)$. Some specimens were dehydrated in ethanol series $(30 \%, 50 \%$, $80 \%$, and $100 \% \mathrm{EtOH}$ ) and were preserved in $100 \%$ methanol. These specimens were rehydrated in ethanol series before microscopic examination using the Leica DM R microscope and/or before the following staining procedure.

Fluorescent immuno- and dye staining and confocal microscopy

Immunohistochemistry was performed as previously described (Yuan et al. 2008). Primary antibodies that were used for this study were reactive against FMRFamide (rabbit, 1:500 dilution, US Biological), GLWamide (rabbit 1676 IIIp, 1:300, provided by Dr. T. Leitz; for detail information of this antibody, see Schmich et al. 1998), tyrosinated tubulin (tyrTub; mouse, 1:800, Sigma), acetylated Tubulin (; mouse, 1:1,000, Sigma), and taurine (rabbit, 1:200, Chemicon). Nuclei were labeled using the fluorescent dye TOTO (1:5 in Vectashield mounting medium); filamentous actin was labeled using rhodamine phalloidin $(1: 25)$ or phalloidin conjugated to AlexaFluor 568 ("Pha"). Secondary antibodies that were used for this study were AlexaFluor 568 (rabbit. 1:200, Molecular Probes), AlexaFluor 488 (mouse, 1:200, Molecular Probes), and Cy5 (rabbit, 1:200, Jackson Laboratory). The specimens were mounted in Vectashield (Vector Laboratories
Inc.). Ephyrae in each strobila were separated and individually examined using a Leica TCS-SP laser confocal microscope at the UCLA Brain Research Institute.

Transmission electron microscopy

Transmission electron microscopy (TEM) was performed as previously described (Yuan et al. 2008). A rhopalium of an ephyra was sagitally and serially sectioned by the Microscopic Techniques Laboratory at UCLA and examined using the JEOL 100CX transmission electron microscope at the Electron Microscope Laboratory of the UCLA Brain Research Institute.

\section{Results}

Neuromuscular system in the free-swimming ephyra

In principle, the scyphozoan neuromuscular system in ephyra larvae is anatomically and physiologically comparable to adults (Horridge 1956a), although some differences are known (cf. Schwab 1977). Actin-rich myofibrils of epitheliomuscular cells can be labeled by phalloidin. In the subumbrellar (i.e., oral) ectoderm in an ephyra, myofibrils are concentrated around the bell margin, forming circumferentially oriented "circular/coronal muscle" around the manubrium (Fig. 2a, b), and along the rhopalar arm, forming a pair of radially oriented "radial muscles" flanking each rhopalium (Fig. 2c, d). These myofibrillar systems are closely associated with the MNN, which is strongly immunoreactive (IR) to the antibody against tyrTub (Fig. 2a, c). The MNN contains highly vacuolated, large bipolar ganglion cells with thick neuronal processes that extend parallel to the radial and circular muscle fibers (Fig. 2a, c, e; Horridge 1956a; Anderson and Schwab 1981). TyrTub-IR fibers connect the MNN to neurons in the rhopalium (white arrows in Fig. 2c; see below).

The tyrTub antibody presumably labels all tubulincontaining cells (e.g., epithelial cells including neurons) and organelles (e.g., cilia and neurites). However, the MNN is strongly tyrTub-IR relative to other cell types, likely due to the presence of highly enriched microtubules in MNN axons (Anderson and Schwab 1981). An anti-taurine antibody reacts with approximately $50 \%$ of the tyrTub-IR MNN along the radial (and circular) muscle, and with a subset of ectodermal sensory cells in the rhopalium (Fig. 2g; see below).

An antibody against FMRFamide (Phe-Met-Arg-Phe$\mathrm{NH}_{2}$ ) serves as a marker for the DNN that underlies the entire body wall (subumbrellar and exumbrellar DNN) and also surrounds the radial and circular muscle (Fig. 2b, d) in ephyrae (Carlberg et al. 1995; Satterlie 2002). The 
Fig. 2 Ephyra neuromuscular system. Confocal sections of Aurelia sp. 1 ephyrae labeled with antibodies against tyrosinated tubulin $($ tyrTub), taurine $(T a u)$, and/or FMRFamide $(F M R F)$. In a-d, radial $(\mathrm{rm})$ and circular $(\mathrm{cm})$ muscle fibers are labeled with phalloidin (Pha). In $\mathbf{h}$, nuclei $(n u)$ are labeled with the fluorescent dye TOTO. In all subpanels, ephyrae are viewed from the oral side: $\mathbf{a}, \mathbf{b}$ manubrium and surrounding subumbrellar epithelium of the bell, $\mathbf{c}-\mathbf{h}$ rhopalar arm. The tyrTub antibody strongly labeled the motor nerve net (MNN) (a, c, e), which contains large bipolar neurons (white arrow in e) with longitudinally oriented thick neuronal processes (arrowheads in e). TyrTub-IR cnidocytes with apically located region devoid of staining, presumably occupied by nematocysts $(\mathrm{nm})$, are also seen in the ectoderm (red arrow in $\mathbf{c}$, e; inset in $\mathbf{h}$ ). The taurine antibody labeled a subset of MNN neurons and sensory cells in the rhopalium ( $r h$ ) (arrows in $\mathbf{g}$ ). The FMRFamide antibody labeled the diffuse nerve net (DNN) (b, d-f), which contains multipolar neurons with thin neuronal processes (arrows in f). The tyrTub-IR cnidocytes lie alongside FMRFamide-IR DNN neuronal cell bodies and neurites (see red arrows in e), potentially indicating the presence of nervous communication. $\mathrm{cm}$ circular muscle, $m n$ manubrium, $g f$ gastric filaments, $m n n$ motor nerve net, $d n n$ diffused nerve net, $r h$ rhopalium, $c n$ cnidocil, $\mathrm{nm}$ nematocyst, $n u$ nucleus

FMRFamide-IR neurons appear mostly multipolar with thin neuronal processes (Fig. 2f), as described for typical DNN neurons (Horridge 1956a). The FMRFamide-IR DNN fibers are seen to connect to the rhopalium at the base preferentially at the lateral regions (white arrows in Fig. 2d). As in the MNN, the DNN is immunoreactive against the tyrTub antibody, but immunoreactivity is much weaker in the DNN, presumably because the neuronal processes of the DNN are much thinner and/or the density of microtubules is lower in the DNN.

Associated with the MNN and DNN are cnidocytes, which are also labeled by the tyrTub antibody (red arrows in Fig. 2c, e). Cnidocytes are oriented perpendicular to neuronal processes and mesoglea and contain an apical nematocyst (devoid of staining), basally compressed nuclei, as well as cilia projecting to the external environment (cnidocils; Fig. 2h). Cnidocytes lie alongside cell bodies and/or neurites of the FMRFamide-IR DNN (Fig. 2e), suggesting that the DNN may innervate the cnidocytes to control the nematocyst discharge. FMRFamide-IR neurons have been shown to be closely associated with clusters of cnidocytes in Cubozoa and Hydrozoa (Anderson et al. 2004). Furthermore, innervation of cnidocytes by sensory and/or ganglion cells has been demonstrated by TEM in the anthozoan, Aiptasia pallida, and in the hydrozoan, Hydra (Westfall 2004). Hence, cnidocyte innervation by (peptidergic) neurons could be a common feature in Cnidaria.

In accordance with the histological findings of Horridge (1956a), our immunohistochemical study does not provide evidence for the presence of endodermal neurons in Aurelia ephyrae, although there are other scyphozoans known to possess a gastrodermal nerve net consisting primarily of large bipolar neurons (Passano and Passano 1971). Previ-
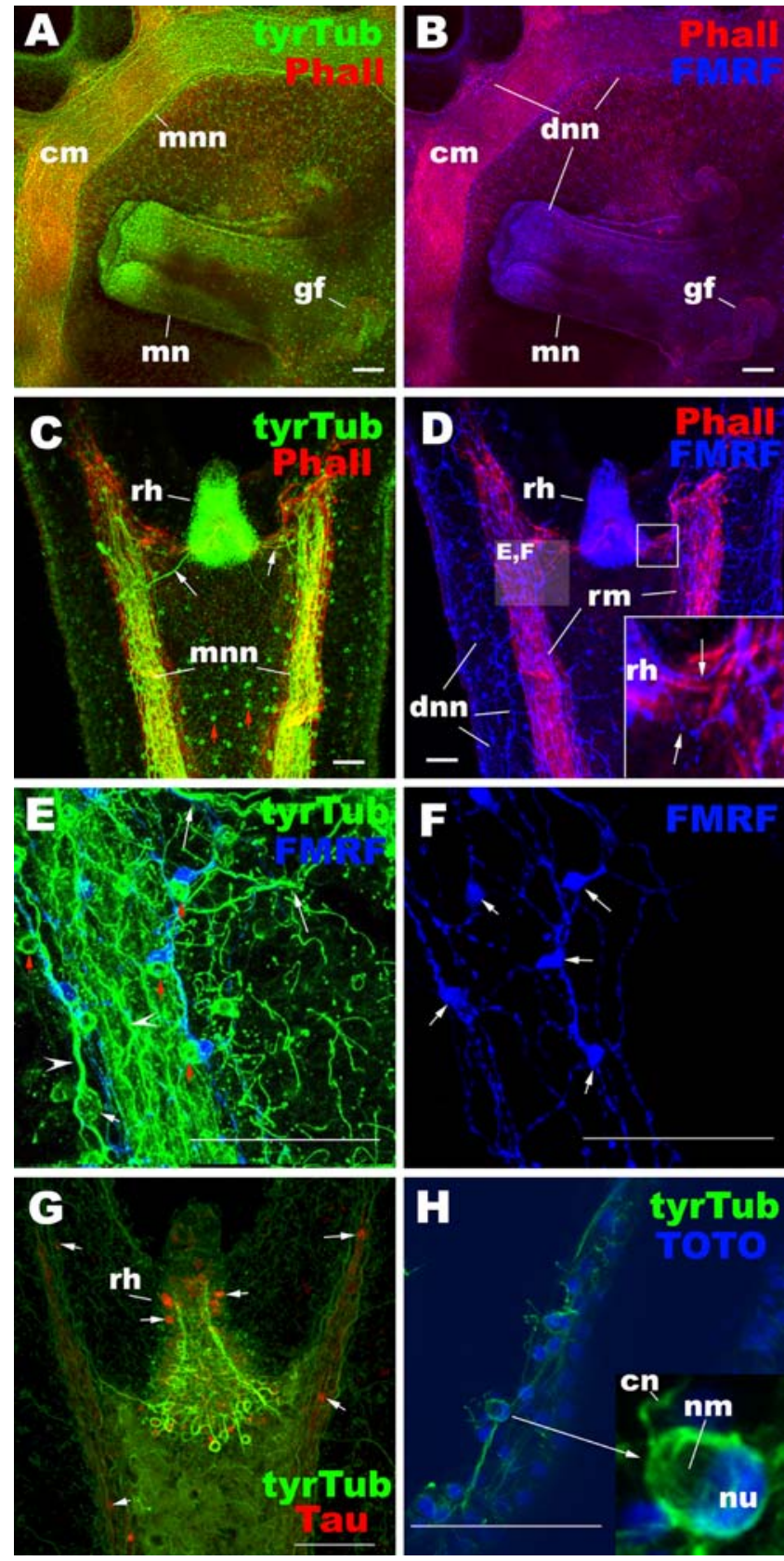

ously, both FMRFamide and taurine antibodies have been reported to label the endodermal neurons in the scyphozoan, Cyanea capillata (Carlberg et al. 1995).

Rhopalia in the free-swimming ephyra

The rhopalium represents an elongated process that is subdivided by two shallow grooves into three segments, called the "terminal," "intermediate," and "basal" segment (Schafer 1878). The terminal segment refers to the region of the lithocyst (Fig. 3d). The intermediate segment contains ocelli and the touch plate, as well as a solid core of 
endodermal cells (Fig. 3d). The basal segment refers to the wide region with thick pseudostratified ectoderm highly enriched in neurons and endoderm surrounding a (rhopalar) canal that opens into the gastrovascular cavity (Fig. 3d). The terminal and intermediate segments extend into the aqueous environment, while the basal segment forms the attachment to the medusa body. Endodermal cells in the intermediate and basal segments of the rhopalium are enriched with F-actin, as evidenced by intense phalloidin staining (Fig. 3d).

The rhopalial nervous system appears primarily ectodermal and contains neurons immunoreactive to antibodies against tyrTub, taurine, GLWamide, and FMRFamide. Their neuronal processes form multiple networks at the base of the ectoderm in the intermediate and basal segments. First, a network of fibers that is strongly tyrTub-IR and also reacts with anti-taurine can be distinguished (Fig. 3f, g); these fibers are primarily oriented longitudinally, but thick processes cross from one side to another at the base of the oral ectoderm in the intermediate region of the rhopalium (red arrows in Fig. 3e), forming commissure-like structures. At the base of the rhopalium, the tyrTub/taurine-IR neuronal processes exit the rhopalium laterally toward each side of the rhopalar arm to join the MNN (arrowheads in Fig. 3e). Secondly, there are multiple interconnected clusters of FMRFamide-IR neurons (Fig. 3h-j). Rhopalial FMRFamide-IR neuronal processes leave the rhopalium preferentially at the lateral regions of the basal segment to join the DNN (arrowhead in Fig. 3h). Third, one can distinguish a population of GLWamide-IR sensory cells whose neurites are confined to the rhopalium (Fig. 3m; Plickert and Schneider 2004). No neurons were detected in the endoderm. In the following, we will discuss the individual classes of rhopalial neurons whose neurites form these three networks in more detail.

\section{Mechanoreceptor}

As mentioned, the presumptive mechanoreceptor of the rhopalium consists of the lithocyst and the touch plate. The statoliths contained within the endodermal lithocytes are visible under transmitted light microscopy (data not shown). Taurine-immunoreactivity is observed in some of the epidermal sensory cells in the touch plate (Fig. 3g). These aboral sensory cells send basal neuronal processes longitudinally toward the base of the rhopalium to join the tyrTub/taurine-IR neuronal network that is continuous with the adjacent MNN (arrowheads in Fig. 3g). Sensory cells in the touch plate have strongly phalloidin-positive rings at the apical cell surface (Fig. 3o), suggestive of stereocilia or microvilli. Actin filaments are highly enriched in microvilli and stereocilia, and circlets of microvilli or stereocilia surrounding the base of cilia have been observed in the
Fig. 3 Rhopalial nervous system at the ephyra to metephyra stage in Aurelia sp. 1. a-c Schematic representation. a Oral surface view with the terminal end up, the basal end down. b Aboral surface view with the terminal end up, the basal end down. c Lateral view through the center of the rhopalium with the oral side facing down. d-o Confocal sections of rhopalia labeled with antibodies against tyrosinated tubulin (tyrTub), Acetylated tubulin (acTub), taurine (Tau), GLWamide $(G L W)$, and/or FMRFamide (FMRF). Phalloidin $(P h a)$ is used to label filamentous actin. Nuclei are labeled with TOTO. Specimens were imaged from the oral side $(\mathbf{d}-\mathbf{h}, \mathbf{j}-\mathbf{n})$, from the aboral side $(o)$ or from the lateral side $(i)$. d A single section at a medial level. e Sections through the entire rhopalium. The tyrTub-IR neuronal processes are primarily longitudinally oriented (white arrow), but commissure-like structures form in the intermediate segment (red arrows). At the base, the processes connect to the MNN (mnn, arrowheads). f Sections through the oral ectoderm of the intermediate segment (in), with the endoderm (en) in the basal segment partially exposed. The inset shows a magnified view of a section of a cell expressing taurine at high levels. g Sections at the base of the aboral ectoderm of the intermediate segment, showing the base of the touch plate $(t p)$ and associated neuronal processes (arrowheads). h Sections through the entire rhopalium. Note the presence of FMRFamide-IR neurites extending out of the rhopalium at its base (arrowhead). i A single section at the medial level. White arrowheads show neurites that are presumed to connect with FMRFamide-IR subepidermal sensory cells of the cup-ocellus (co), while blue arrowheads show neurites that are presumed to originate from or have neuronal connections with the FMRFamide-IR epidermal sensory cells of the spot-ocellus (so). Note the cluster of coiled cilia $(c i)$ at the apical ends of the subepidermal sensory cells of the cup-ocellus $\left(i^{\prime}\right)$. $\mathbf{j}$ Sections through the oral ectoderm. Note the oral-distal cluster of FMRFamide-IR sensory cells with apical phalloidin-positive rings ( $p r$ ) and knobbed cilia ( $b t$ ) (inset). k A single section at the medial level, showing the FMRFamide-IR oral-proximal sensory cells (red arrows). I A single section at the medial level, showing the FMRFamide-IR oral-proximal ganglion cells whose subepidermal cell bodies are surrounded by tubulin-rich rings (yellow arrows). m Sections through the entire rhopalium. Arrowheads show GLWamide-IR neuronal processes. n A surface view of the oral ectoderm. 0 A surface view of the aboral ectoderm of the intermediate segment. lc lithocyst, te terminal segment, in intermediate segment, $b s$ basal segment, en endoderm, $c a$ rhopalar canal, $o-d$ oral-distal group, $a-l$ aboral-lateral group, $o-c$ oral-central group, $o-p$ oralproximal group, so spot-ocellus, $t p$ touch plate, $c o$ cupocellus, mnn motor nerve net, dnn diffuse nerve net, $b t$ bulbous tip of a cilium, $p r$ phalloidin-positive ring, $c i$ cilia, $n u$ nucleus

touch plate cells by electron microscopy (Spangenberg et al. 1996; Hundgen and Biela 1982). Knobs occur in the tips of cilia on these sensory cells (ephyra, not shown; adult, Supplementary Fig. 1, B).

\section{Ocelli}

Each rhopalium contains two ocelli in the intermediate segment: the pigment-cup ocellus and the pigment-spot ocellus. The pigment-cup ocellus is located on the oral side just proximal to the lithocyst and consists of FMRFamideIR ectodermal subepidermal sensory cells and a cup-shaped layer of endodermal pigment cells (Fig. 3i). The ciliated apical side of the subepidermal sensory cells is inverted and faces the endodermal pigment cell layer. These cilia form 
A. Oral view

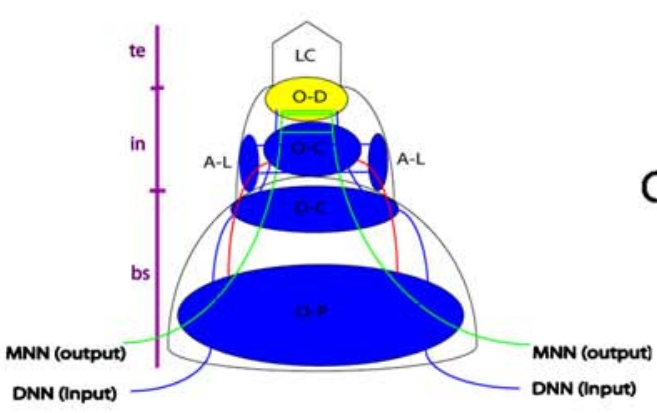

B. Aboral view

C.Lateral view
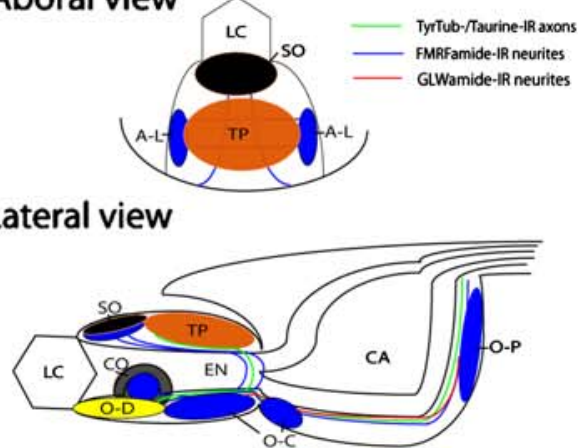
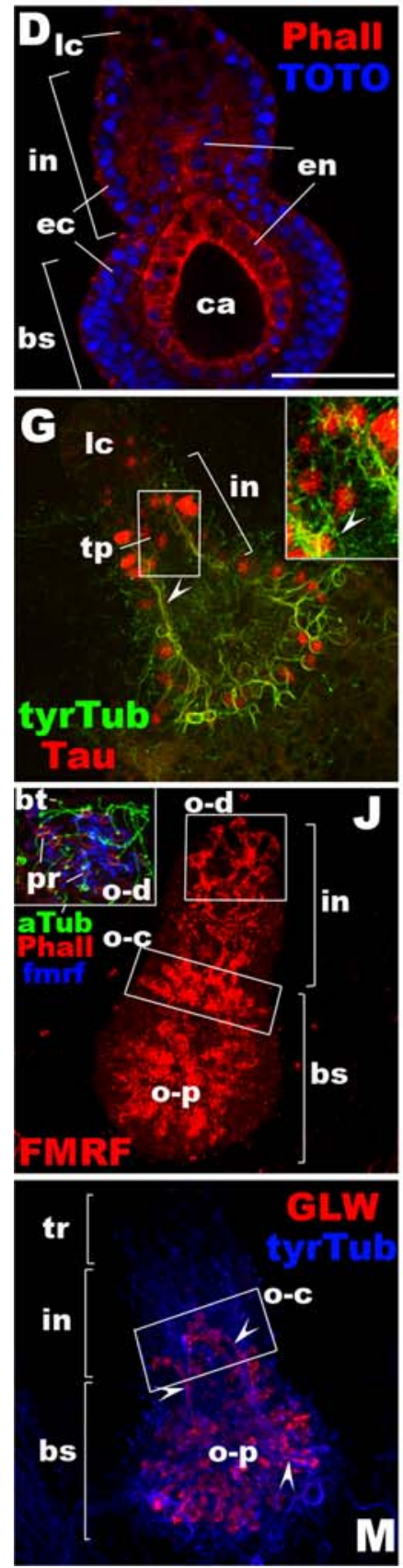
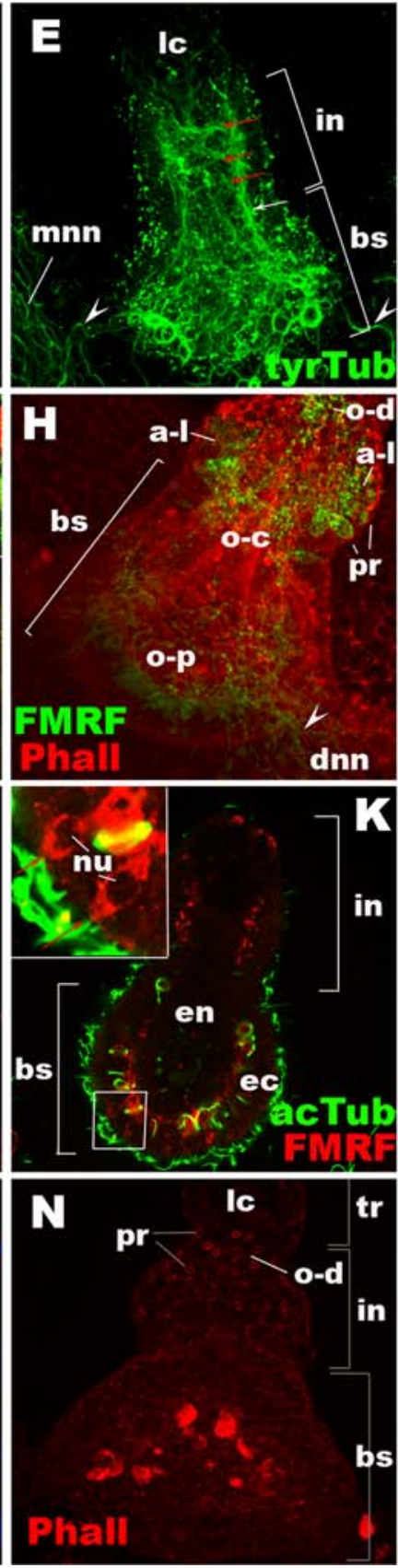
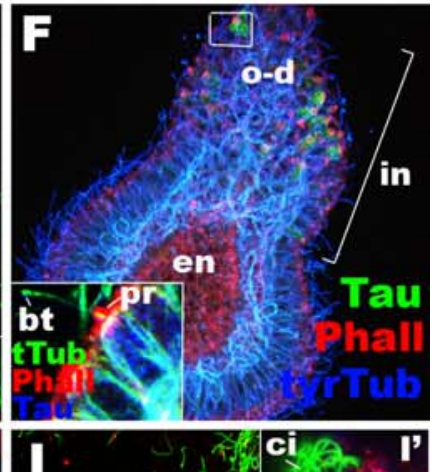

I

in
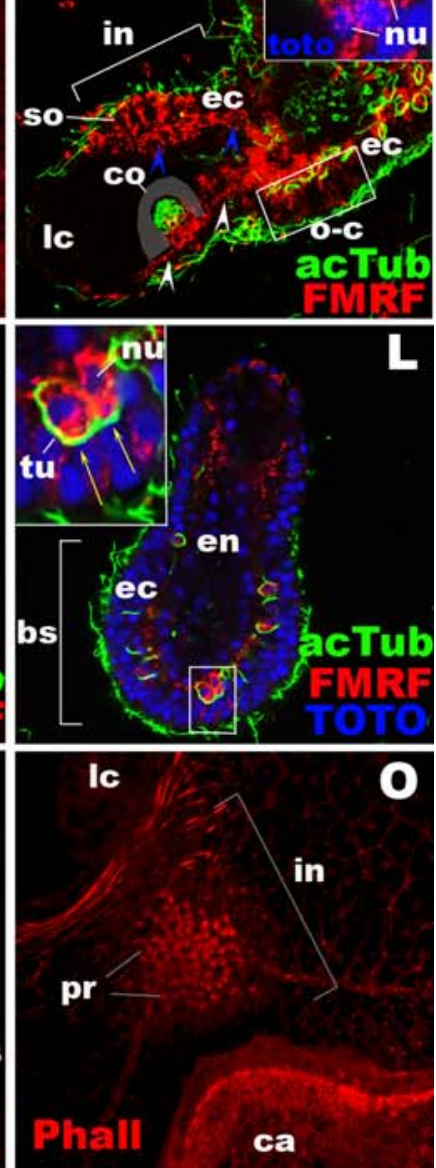
characteristic tight coils (ci in Fig. 3i'). The basal neuronal processes from these sensory cells join the FMRFamide-IR basiepithelial neuronal network that runs longitudinally in the oral ectoderm of the rhopalium (white arrowheads in Fig. 3i).

The pigment-spot ocellus is located on the aboral side just proximal to the lithocyst and distal to the touch plate and consists of ectodermal epidermal pigment cells, some, if not all, of which are FMRFamide-IR (Fig. 3i; Supplementary Fig. 1, A, D). Cilia are long (up to $50 \mu \mathrm{m}$ ) with bulbous tips (Supplementary Fig. 1, D). Basal processes of these FMRFamide-IR cells extend toward the oral side of the rhopalium, becoming part of the FMRFamide-IR basiepithelial neuronal network that is continuous with the DNN at the base of the rhopalium (blue arrowheads in Fig. 3i).

\section{Other neuronal cell types}

Additional clusters of epithelial neurons are found in the rhopalium. We distinguish the oral-distal, aboral-lateral, oralcentral, and oral-proximal groups (Fig. 3a). (1) The oraldistal sensory cells are found on the oral side of the intermediate segment near the lithocyst (terminal segment in adult; Supplementary Fig. 1, C) and have strongly phalloidin-positive rings surrounding the base of bulbous tipped cilia at the apical cell surface. They include cells immunoreactive for taurine, and/or FMRFamide (Fig. 3f, j). The oral-distal sensory cells extend basal axons that project toward the base of the rhopalium. Taurine-IR processes join the tyrTub/taurine-IR neuronal networks continuous with the MNN (Fig. 3f), and FMRFamide-IR processes join the FMRFamide-IR networks continuous with the DNN (Fig. 3h). Although stereocilia have previously been reported only from the touch plate neurons (see above), we identified them on the oral side of the rhopalium via TEM (Fig. 4), which is consistent with the occurrence of strongly phalloidin-positive rings on the oral side (Fig. 3n). Observed stereocilia contain dense filaments that extend into the cytoplasm (Fig. 4b), and apparently coordinated bending of cilia and stereocilia is observed (Fig. 4a), as is seen in the touch plate "hair cells" (Spangenberg et al. 1996). (2) The aboral-lateral sensory cells are FMRFamide-IR and possess strongly phalloidin-positive rings at the apical cell surface as well (Fig. 3h). These cells form two small clusters arranged in bilateral symmetry flanking the region of the touch plate on the aboral side of the intermediate segment of the rhopalium. Each cluster sends basal processes toward two directions: one to the cluster on the opposite side of the rhopalium, forming commissure-like structures at the base of the touch plate ectoderm, and the other to the oral side of the rhopalium to join the neuronal network continuous with the DNN. (3) The oral-central group of epidermal sensory cells is located in the oral ectoderm encompassing the proximal region of the intermediate segment and the distal region of the basal segment. Those in the intermediate segment are GLWamide-IR (Fig. 3m), while those in the basal segment are FMRFamide-IR (Fig. 3j). GLWamide-IR sensory cells in this region send basal neuronal processes toward the basal segment to connect to the developing GLWamide-IR basiepithelial neuronal network in the basal segment (arrowheads in Fig. $3 \mathrm{~m}$ ). Basal neuronal processes of FMRFamide-IR oral-central sensory cells form a dense network that is connected to other neuronal clusters by longitudinally oriented neurites (Fig. 3h, i). It remains to be determined whether strongly phalloidin-positive rings occur at the apical cell surface of the GLWamide-IR cells in the intermediate segment, although the density of the phalloidin-positive rings in the proximal region of the intermediate segment is low (Fig. 3n). FMRFamide-IR oral-central cells lack the apical phalloidin-positive rings (Fig. 3h). (iv) The oral-proximal group is located in the ectoderm preferentially toward the proximal side of the basal segment (Fig. 3j-m). This group contains cells immunoreactive to antibodies against FMRFamide and/or GLWamide, and they lack apical phalloidin rings. The oral-proximal FMRFamide-IR neurons include epidermal sensory cells as well as presumed ganglion cells with subepidermal cell bodies characteristically surrounded by tubulin-rich rings of unknown function (Fig. 3k, 1). Neuronal processes from these FMRFamide-IR cells form the most basally located network in the rhopalium. This network is connected to other, more distally located FMRFamide-IR neuronal clusters in the rhopalium via a limited number of longitudinally oriented neurites residing on either side of the rhopalium, as well as to the DNN via projection of neurites from the lateral regions of the base of the rhopalium (Fig. 3h). GLWamide-IR cells in this group also include epidermal sensory cells (Fig. $3 \mathrm{~m}$ ), and ganglion cells similar in spatial distribution and structure to the FMRFamide-IR oral-proximal ganglion cells were identified at a later stage (data not shown). No GLWamide-IR neurites were observed to make neuronal connections with cells outside of the rhopalium.

Cell bodies of tyrTub-IR neuronal processes in the rhopalium could not be unambiguously identified by tyrTub labeling, as all epithelial cells are tyrTub-IR at roughly equal levels in free-swimming ephyrae. However, as strongly tyrTub-IR neuronal processes in the rhopalium are also taurine-IR, we assume that taurine-IR cells constitute (at least) a subset of neurons that generate strongly tyrTub-IR, thick neuronal processes. In addition to the touch plate region and the region of the oral-distal sensory cell group, cells expressing taurine at lower levels are found at high density throughout the ectoderm in the intermediate and basal segments (Fig. 3g), basal processes from which presumably contribute to the dense network of 


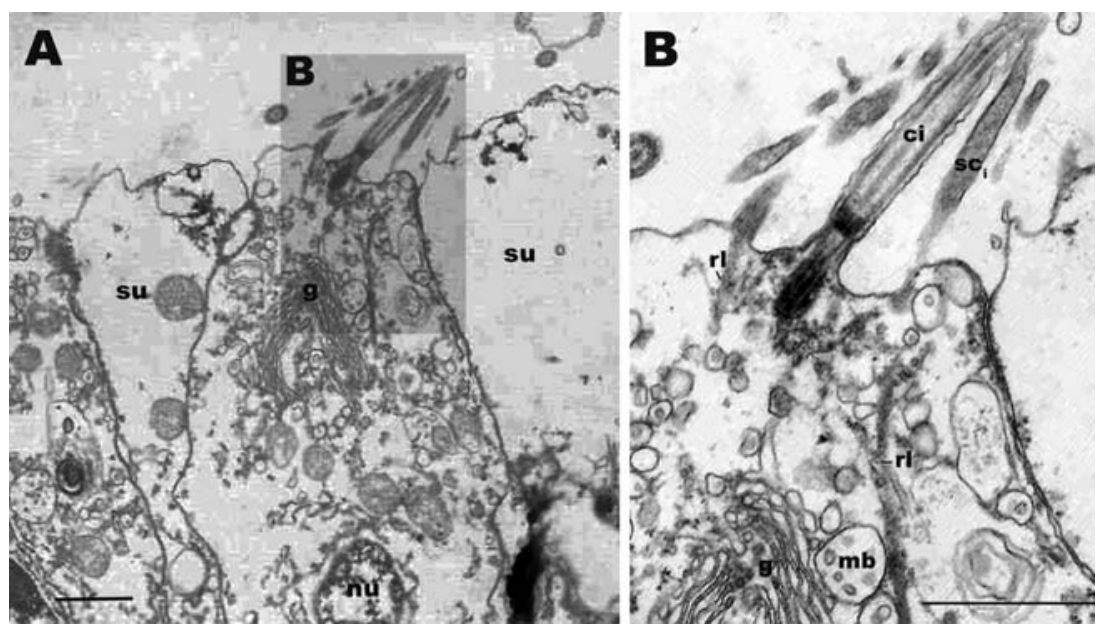

Fig. 4 Stereocilia on the apical cell surface of oral ectodermal cells in Aurelia sp. 1. a An electronmicroscopic section of the apical surface of epidermal cells in the oral ectoderm. The apical surface is to the top. b A magnified view of the apical region of a cell in a, showing dense filaments of stereocilia ( $\mathrm{sci}$ ) extending into the cytoplasm of the cells forming rootlets $(r l)$. Note the apparently coordinated bending of

strongly tyrTub/taurine-IR neuronal processes in these regions.

Definition of stages in ephyra development

As mentioned, polydisk strobilation is a process by which a polyp produces many transverse "segments," each of which develops into an ephyra. Development initiates at the uppermost segment that transforms directly from the polyp's oral region containing the mouth and tentacles. In this segment, rhopalia develop at the base of interradial and perradial tentacles, and all polyp tentacles eventually degenerate. Rhopalia in other segments do not develop from tentacles but from the polyp body column (Russell 1970). Thus, specification of rhopalial development occurs sequentially from the oral to aboral direction in specific regions in the periphery of each differentiating segment along the strobilating polyp body.

Based on morphological and behavioral characteristics, ephyral development can be broken down into five stages (Table 1). During the first three stages, the developing ephyra forms part of the strobilating polyp (Fig. 1b); we will call these stages prephyra I-III. At the prephyra I stage, rhopalia are unsegmented and oval in shape; lappets are short (less than $100 \mu \mathrm{m}$ long; Fig. 5a, b), and the statolith begins to form at the distal end of the rhopalium (Fig. 5c; see below). At the prephyra II stage, lappets and rhopalia are more elongated, and the terminal, intermediate, and basal segments of the rhopalium can be distinguished (Fig. 5d). At the prephyra III stage, the ephyra begins to show spontaneous beating, in which rhopalar arms (cf. Fig. 1c) contract in unison. The early free-swimming stage the cilium ( $\mathrm{ci}$ ) and stereocilia $(\mathrm{sci})$ in a. Multivesicular bodies $(\mathrm{mb})$ are seen in the apical region closely associated with the Golgi apparatus $(g)$ (b). Similar features were previously reported from touch plate hair cells of Aurelia ephyra (Spangenberg et al. 1996). $r l$ rootlet, $m b$ multivesicular bodies, $g$ Golgi, $c i$ cilium, sci stereocilium, $s u$ supporting cell, $n u$ nucleus

following liberation is called ephyra. The last stage considered, the late ephyra or "metephyra," is primarily defined by the development of a ring canal system along the bell margin (Fig. 1d), which occurs within 3 weeks after liberation (Kawahara et al. 2006; Yasuda 1983).

\section{Pattern of rhopalial development}

The polyp nervous system is ectodermal and concentrated in the oral region, namely, the tentacles, the oral disc, and the mouth (Chia et al. 1984; Nakanishi et al. 2008; Sakaguchi et al. 1999). No neurons are observed in the body column except along the longitudinal cord muscle fibers that connect the oral region to the base of the polyp. Physiological, anatomical, and immunohistochemical evidence indicates that the polyp nervous system is of the DNN type. First, the DNN-mediated behaviors of feeding and spasm (cf. Horridge 1956a), but not the MNN-mediated behavior of periodic

Table 1 List of characters that define each developmental stage in Aurelia sp. 1

\begin{tabular}{ll}
\hline Stage & Defining characteristics \\
\hline Prephyra I & $\begin{array}{c}\text { Rhopalia oval shape. A few } \\
\text { statoliths at the distal ends } \\
\text { Rhopalia elongated. Terminal, } \\
\text { intermediate and basal segments } \\
\text { can be distinguished }\end{array}$ \\
Prephyra II & Onset of spontaneous coordinated \\
& muscle contraction \\
Prephyra III & Free swimming \\
Ephyra & Presence of ring canals \\
Late ephyra (metephyra) &
\end{tabular}



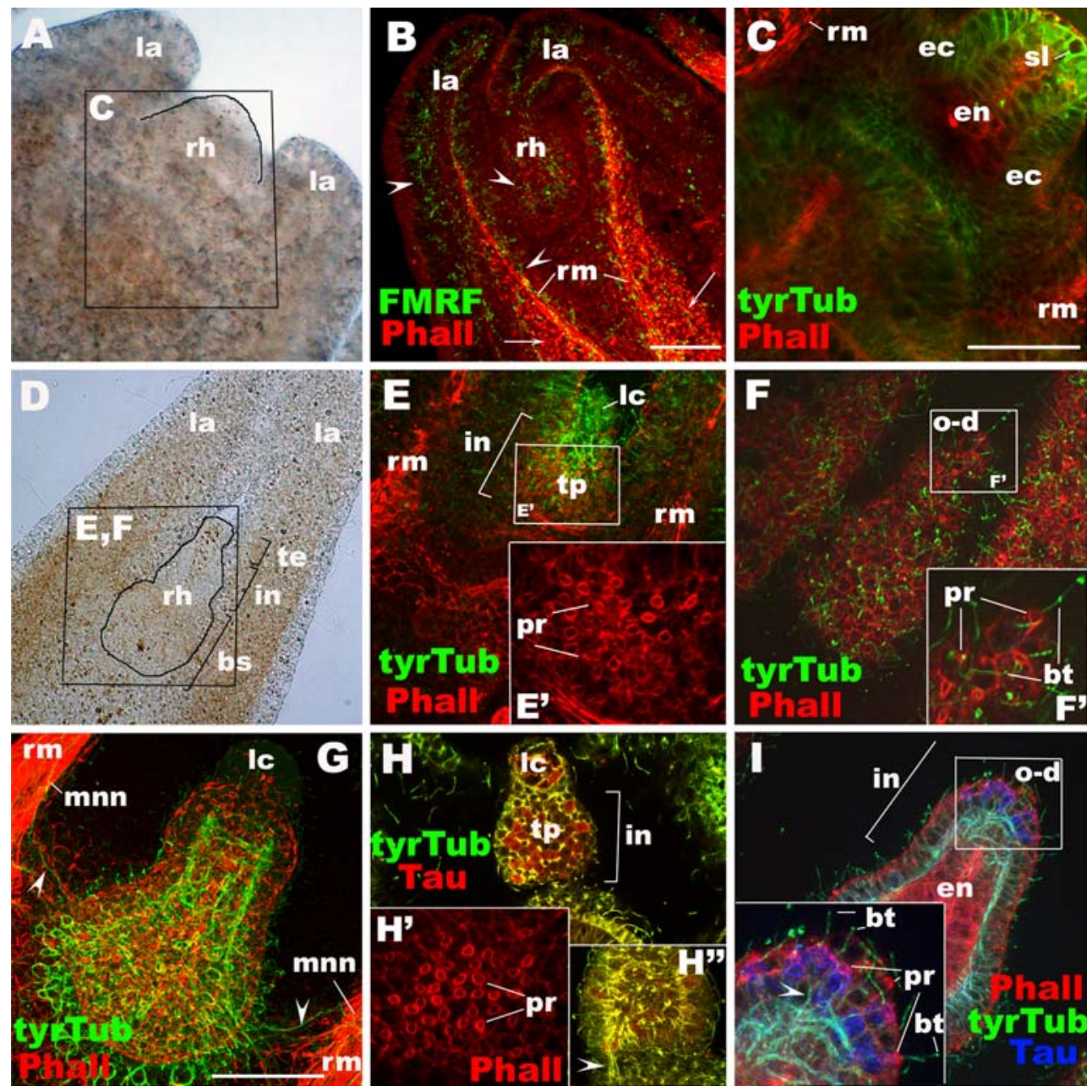

Fig. 5 Development of presumptive mechanoreceptors in Aurelia sp. 1: the lithocyst $(l c ; \mathbf{c}, \mathbf{e}, \mathbf{g}, \mathbf{h})$, the touch plate $(t p ; \mathbf{e}, \mathbf{h})$, and the oraldistal $(o-d)$ group of sensory cells near the lithocyst (f, i; see also Fig. 7f). a-c Prephyra I. d-f Prephyra II. g-i Prephyra III. b, c, e-i Confocal sections of developing rhopalia labeled with antibodies against FMRFamide $(F M R F)$ or Taurine (Tau) and/or tyrosinated tubulin (tyrTub) and/or the fluorescent dye phalloidin (Pha). In all subpanels, specimens are imaged from the oral side. a A bright-field image of the rhopalar arm. b Sections through the rhopalar arm. The arrows show actin-rich myofibrils. Arrowheads show FMRFamide-IR neurites. c A single section at the aboral-medial level, showing the presence of a statolith $(s l)$. d A bright-field image of the rhopalar arm. e, $e^{\prime}$ a surface view of the touch plate $(t p)$, showing phalloidin-positive rings $(p r)$. $\mathbf{f}, f^{\prime}$ an oral surface view. Note the presence of phalloidinpositive rings $(p r)$ surrounding the base of knobbed cilia $(b t)$ in the

pulsations, are observed at the polyp stage (Passano 1965; Schwab 1977). Second, a TEM study identified only a single diffuse ectodermal sensory nerve net (Chia et al. 1984). Third, the immunohistochemical analysis showed that the polyp neurons are immunoreactive to an antibody against RFamide (Sakaguchi et al. 1999), as is the case with the DNN of Aurelia ephyrae (Plickert and Schneider 2004). Thus, during strobilation, the medusa DNN in the uppermost segment "develops" directly from the polyp DNN, which region of the future oral-distal neurons $(o-d)$. $\mathbf{g}$ Sections through the rhopalium. Arrowheads show tyrTub-IR neuronal processes that connect the MNN (mnn) and tyrTub-IR rhopalial nervous system. h, $h^{\prime}, h^{\prime \prime}$ Sections at the level of the touch plate $(t p)$, at the apical surface $\left(h^{\prime}\right)$ and at the base $\left(h^{\prime \prime}\right)$. Note the presence of phalloidin-positive rings (pr) at the apical surface of the touch plate $\left(h^{\prime}\right)$, and tyrTub/taurine-IR neuronal processes that originate from the base of the touch plate cells and longitudinally extend toward the basal segment of the rhopalium (arrowhead in $\left.h^{\prime \prime}\right)$. i Sections through the oral-distal sensory cells ( $o$ $d$ ), showing their bulbous tipped cilia ( $b t$ ), apical phalloidin-positive rings ( $p r)$, and basal neurites (arrowhead). rm radial muscle, $s l$ statolith, $r h$ rhopalium, la lappet, $l c$ lithocyst, ec ectoderm, en endoderm, $t r$ terminal segment, in intermediate segement, $b s$ basal segment, $p r$ phalloidin-positive ring, $o-d$ oral-distal group, $c i$ cilium, $b t$ bulbous tip of a cilium, mnn motor nerve net

therefore precedes development of rhopalia, while the lower segments must develop the DNN de novo.

\section{Prephyra I}

During the prephyra I stage, the lithocyst and the epitheliomuscular system begin to differentiate. In addition, several subsets of sensory neurons make their appearance. Lithocyst differentiation is evidenced by the presence of a dark, 
polygonal space outlined by tyrTub-IR cytoskeleton, presumably representing the trace of a statolith in a lithocyte, at the terminal end of the rhopalium (Fig. 5c). Actin-rich myofibrils of radial muscles are observed in the rhopalar arms extending into developing lappets; they appear discontinuous relative to those in the free-swimming ephyra (arrows in Fig. 5b; compare with Fig. 2d), suggesting that the myofibrillar systems have not fully differentiated yet. Longitudinally oriented FMRFamide-IR neurites are found on the subumbrellar epithelium along the radial muscle fibers and the most proximal region of the rhopalium, as well as on the exumbrellar epithelium (arrowheads in Figs. $5 \mathrm{~b}$ and $6 \mathrm{~b}$ ); neurites in the rhopalium at least partially originate from the developing oral-proximal neurons (o-p in Fig. 6b). GLWamide-IR oral-proximal neurons are also observed (arrows in Fig. 6a), but basal neuronal processes have not extended. In addition, two small clusters of FMRFamide-IR neurons arranged in bilateral symmetry representing the aboral-lateral group (a-1 in Fig. 6c), as well as taurine-IR ectodermal neurons at the lateral side of the intermediate segment near the developing lithocyst (arrows in Fig. 6d) are observed in the rhopalium. Neurites from these cells have not yet extended, suggesting that they are at an early stage of differentiation. The observed taurine-IR neurons do not correspond to those in the oral-distal group based on their position.

\section{Prephyra II}

Terminal, intermediate, and basal segments of the rhopalium can now be distinguished (Fig. 5d). All groups of neurons except for sensory cells associated with ocelli and oral-central GLWamide sensory cells have appeared and are represented by small groups of cells that are immunoreactive for FMRFamide, taurine, or GLWamide and/or cells that have phalloidin-positive rings at the apical cell surface. Neurons of the touch plate and aboral-lateral sensory cells (Figs. 5e, $\mathrm{e}^{\prime}$ and $6 \mathrm{~g}$ ), as well as a few neurons of the oraldistal group close to the lithocyst (Figs. 5f, $\mathrm{f}^{\prime}$ and $6 \mathrm{f}$ ) exhibit the phalloidin-positive rings. Some of the rings are seen to surround the base of knobbed cilia (Fig. 5f'). Among the FMRFamide-IR oral-proximal neurons, sensory cells and immature ganglion cells are found (arrows in Fig. 6h). The former have cell bodies located within the ectodermal epithelium, oriented perpendicular to the mesoglea. Presumptive ganglion cells lack contact with the apical surface; however, the tubulin-rich rings characteristic for cell bodies of ganglion cells at the ephyra stage have not yet developed. Neuronal processes of FMRFamide-IR neurons of each group (oral-distal, aboral-lateral, oral-central, and oral-proximal) now form an interconnected network that is continuous with the DNN at the base of the rhopalium (arrowheads in Fig. 6f). Two longitudinally oriented neurites are seen to connect the neurons in the oralproximal group with those in the oral-central, oral-distal, and aboral-lateral groups (arrowheads in Fig. 6f). Bilaterally arranged clusters of aboral-lateral FMRFamide-IR sensory cells send neurites toward the oral ectoderm to join the neuronal network on the oral side, as well as to each other to form the commissure-like structures at the base of the aboral ectoderm (Fig. 6f; arrowhead in Fig. 6g). GLWamide-IR cells also begin to form basal neuronal processes (arrowheads in Fig. 6e). Immunoreactivity against the taurine antibody begins to occur in ectodermal cells in the basal segment of the rhopalium (data not shown).

\section{Prephyra III}

At this stage, strong expression of taurine in touch plate cells as well as in the oral-distal group of cells is evident (Fig. 5h, i). The tyrTub/taurine-IR neurons extend neurites longitudinally toward the base of the rhopalium, where they connect to the developing MNN (Fig. 5g, h", i). This structural maturation coincides with the occurrence of coordinated beating, suggesting that the pacemaker function of the marginal center is active. In the basal segment of the rhopalium, longitudinally oriented GLWamide-IR neurites extending along the mesoglea are observed (arrowhead in Fig. 6i), and FMRFamide-IR oral-proximal sensory cells and ganglion cells can be clearly distinguished (arrows in Fig. 6k, 1); FMRFamide-IR ganglion cell bodies are now surrounded by tubulin-rich rings (data not shown). The number and density of FMRFamide-IR neurons and their basal processes have increased, particularly in the oraldistal, aboral-lateral, and oral-proximal groups (Fig. 6j).

\section{Ephyra stage}

At the ephyra stage, the pigment-cup ocellus begins to develop. On the oral side in the intermediate segment of the rhopalium just proximal to the oral-distal cluster of sensory cells, coiled cilia are observed at the base of the FMRFamide-IR ectodermal neurons in close contact with endodermal pigment cells (Fig. 7a, $\mathrm{a}^{\prime}$ ). This suggests that the apical surface of the FMRFamide-IR subepidermal (sensory) cells associated with the pigment-cup ocellus now faces the endoderm. The endodermal pigment cells contain conspicuous dark pigment granules at this stage and thus are readily distinguished from the rest of the endoderm (Fig. 7b, b'). Invagination of the pigment-cup ocellus has yet to occur. Oral-central GLWamide-IR sensory cells develop in the ectoderm of the intermediate segment and send basal neuronal processes longitudinally toward the basal segment to form a network with the oral-proximal GLWamide-IR neurons (Fig. 3m). 

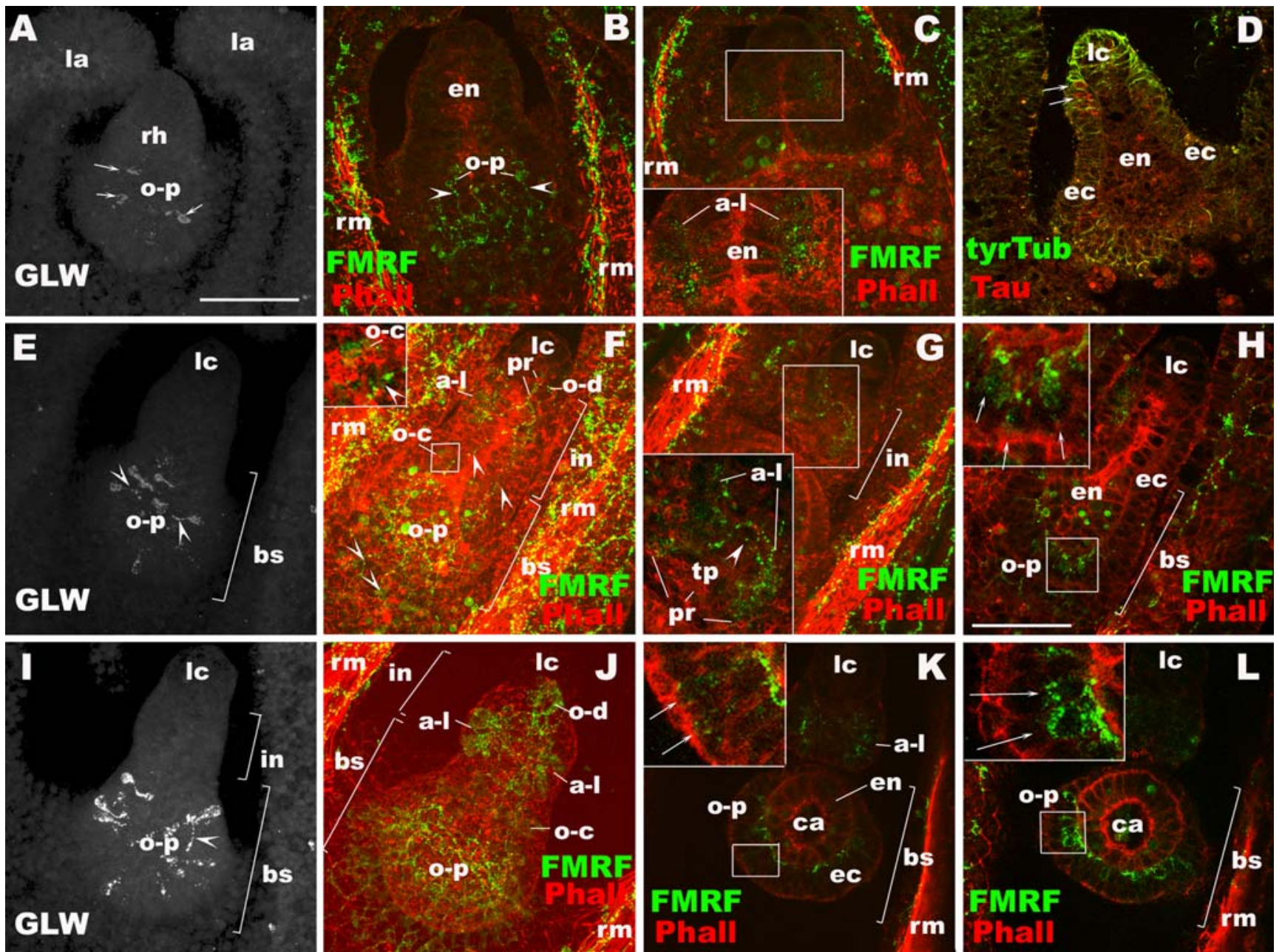

Fig. 6 Development of rhopalial neurons outside of mechanoreceptors and ocelli in Aurelia sp. 1. a-d Prephyra I. e-h Prephyra II. iI Prephyra III. Confocal sections of rhopalia labeled with antibodies against tyrosinated tubulin (tyrTub), taurine (Tau), GLWamide (GLW), and/or FMRFamide $(F M R F)$. Phalloidin $(P h a)$ is used to label filamentous actin. In all subpanels, specimens were imaged from the oral side. a Sections through the rhopalium, showing the oralproximal group $(o-p)$ of GLWamide-IR sensory cell bodies without basal processes (arrows). b Sections through the oral-medial portion of the rhopalium, showing FMRFamide-IR oral-proximal neurons $(o-$ p) and their neurites (arrowheads). c A single section at the aboralmedial level, showing the presence of FMRFamide-IR aboral-lateral cells $(a-l)$ without clear basal processes (inset). d A single section at the medial level, showing taurine-IR cells at the base of the ectoderm at the lateral side near the differentiating lithocyst (lc) (arrows). e Sections through the rhopalium, showing the formation of GLWamide-IR neurites (arrowheads). f Sections through the rhopalium, showing the oral-distal $(o-d)$, aborallateral $(a-l)$, oral-central $(o-$ $c$; inset) and oral-proximal (o-p) groups of FMRFamide-IR cells and

\section{Late ephyra (metephyra) stage}

At the late ephyra stage, or the "metephyra" stage, the pigment-cup ocellus develops further, and the pigment-spot ocellus differentiates. A layer of endodermal pigment cells in the pigment-cup ocellus forms a cup, within which a mass of
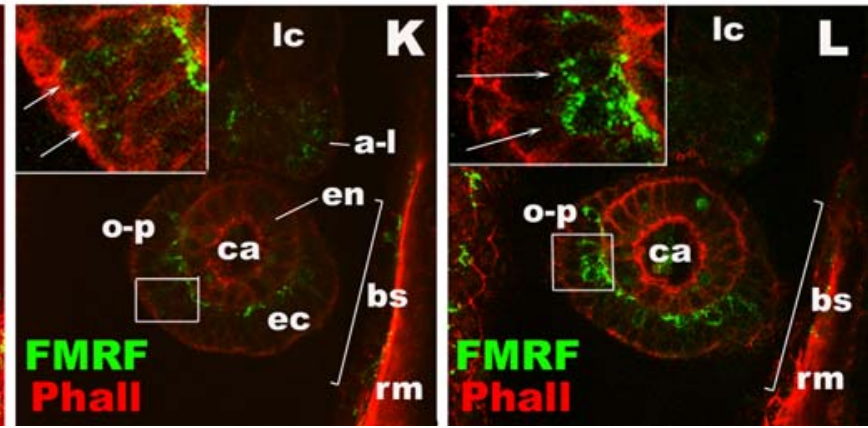

longitudinally oriented neuronal processes (arrowheads) connecting each of the clusters and the DNN outside of the rhopalium. g Sections at the level of FMRFamide-IR aboral-lateral sensory cells, showing the development of apical phalloidin-positive rings $(p r)$ and their basal processes (arrowhead) forming commissure-like structures at the base of the touch plate $(t p)$. h A single section at the medial level, showing FMRFamide-IR oral-proximal neurons (arrows). i Sections through the rhopalium, showing the oral-proximal group of GLWamide-IR sensory cells. Note the presence of a longitudinally oriented basal process (arrowhead). $\mathbf{j}$ Sections through the rhopalium, showing all major FMRFamide-IR neurons. $\mathbf{k}$ A single section at the aboralmedial level, showing FMRFamide-IR oral-proximal sensory cells (arrows). I A single section at the aboral-lateral level, showing FMRFamide-IR oral-proximal ganglion cells (arrows). Note their subepidermal position. $r h$ rhopalium, la lappet, $r m$ radial muscle, $o-p$ oral-proximal neuron, $a-l$ aborallateral neuron, en endoderm, ec ectoderm, in intermediate segment, $b s$ basal segment, $l c$ lithocyst, $p r$ phalloidin-positive ring, $o-d$ oral-distal neuron, $o-c$ oral-central neuron, $t p$ touch plate, $c a$ rhopalar canal

internalized subepidermal sensory cells is housed (Fig. 3i). Pigment granules are observed on the aboral side of the rhopalium just proximal to the lithocyst (Figs. $1 \mathrm{~g}$ and $7 \mathrm{c}$ ), and a new population of FMRFamide-IR epidermal sensory cells occur in this region (Figs. $3 \mathrm{i}$ and 7c), indicating that the pigment-spot ocellus is undergoing differentiation at this 

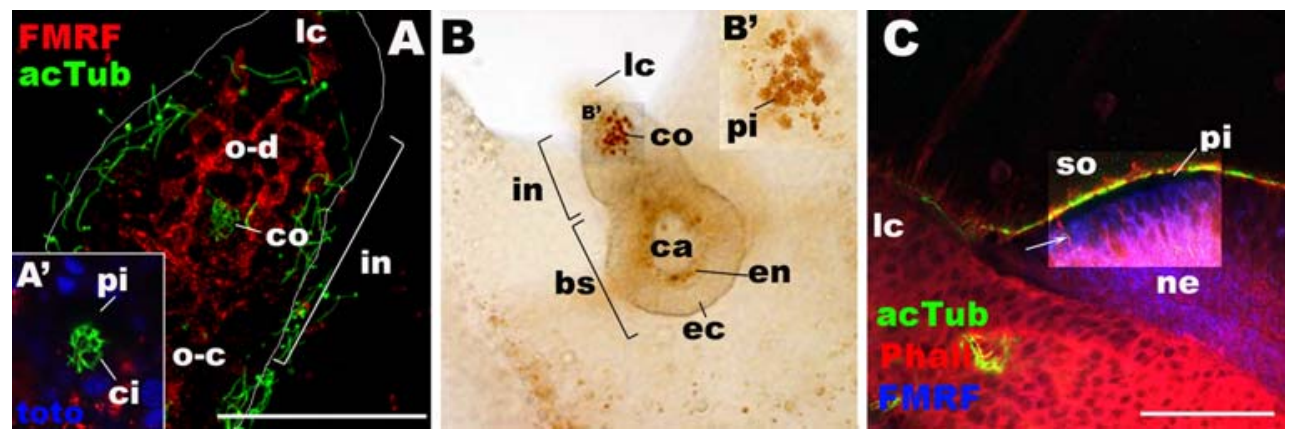

Fig. 7 Light microscopic examinations of developing ocelli in Aurelia sp. 1. a, b Ephyra. c Metephyra. In a and c, rhopalia are labeled with antibodies against FMRFamide $(F M R F)$ and acetylated tubulin $(a c T u b)$. In $\mathbf{c}$, phalloidin $(P h a)$ is used to label filamentous actin. a, $a^{\prime}$ Sections at the levels of the oral ectoderm, viewed from the oral side. In a, sections are taken from the apical cell surface (cilia not shown) of the oral ectoderm in the intermediate segment through the level of the internalized cilia of the developing cup-ocellus $(c o)$ at the base of the oral ectoderm. $a^{\prime}$ is a single section at the base of the oral ectoderm in the developing cup-ocellus. Note the coiled cilia $(\mathrm{ci})$ and surrounding dark space where endodermal pigment cells are located.

stage. Notably, invagination of the pigment-spot epithelium and lengthening of cilia are observed in this region toward the adult stage (Supplementary Fig. 1, A, D; compare with Figs. $3 i$ and $7 c$ ).

\section{Discussion}

Rhopalial nervous system in the ephyra

Horridge (1956a) made a histological observation of the rhopalial nervous system of Aurelia ephyrae, hypothesizing that four cell types interconnected to form a bilaterally symmetrical neuronal network that would receive sensory input from the DNN and send output into the MNN. There is, however, a missing component: the input from the rhopalial sensory system. Our data show that the rhopalial nervous system contains at least seven sensory-cell groups - oral-distal, aboral-lateral, oral-central, oral-proximal groups, the touch plate, pigment-cup, and pigment-spot ocelli-consisting of FMRFamide-, GLWamide-, and/or taurine-IR ectodermal sensory cells (Fig. 3). These sensory cells have neuronal processes at the base, forming bilaterally symmetrical, basi-epithelial neuronal networks that are connected to the nervous system outside of the rhopalium: the DNN via the FMRFamide-IR processes and the MNN via the taurine- and tyrTub-IR processes (Fig. 3). These neuroanatomical data therefore confirm Horridge's finding that the neurocircuit of the rhopalial nervous system is continuous with the rest of the medusa nervous system and suggest that sensory input received from the rhopalial sensory cells directly enters the neuronal networks of the rhopalium. $\mathbf{b}, \mathbf{b}^{\prime}$ a bright-field image of the rhopalium, viewed from the oral side, showing accumulated pigment granules ( $p i)$ in the cup-ocellus (co). c A single section of the spot-ocellus ( $s o$ ) at the medial level, viewed from the lateral side. Lithocyst $(l c)$ is to the left. Notice a cluster of FMRFamide-IR sensory cells (arrow) whose apical ends appear dark due to pigmentation ( $p i)$; basal neuronal processes (ne) are sent toward the oral-basal direction. $l c$ lithocyst, $o-d$ oral-distal group, $o-c$ oralcentral group, co pigment-cup ocellus, so pigment-spot ocellus, $p i$ pigment granules, $c i$ cilium, in intermediate segment, $b s$ basal segment, ec ectoderm, en endoderm, $c a$ rhopalar canal, ne neuronal processes

With the neuroanatomical information presented in this study, it is possible to deduce hypotheses about the conduction pathways of sensory input from rhopalia. FMRFamide-IR neurons constitute the DNN outside of the rhopalium, and an electrophysiological study indicated that DNN impulses did not originate from the rhopalia (Passano 1965). Furthernore, GLWamide-IR neurites do not appear to extend out of the rhopalium. Thus, it appears likely that electrical impulses traveling through the neurites from the FMRFamide- and GLWamide-IR sensory cells do not propagate directly from the rhopalium. Because sensory input from the rhopalia often influences the rate of swimming contractions (Horridge 1959), which is under a direct control of the marginal center in the rhopalium (Horridge 1956b; Passano 1965), the most likely function of FMRFamide- and GLWamide-IR sensory cells in the rhopalium would be to modulate the pacemaker activity of the marginal center. On the other hand, taurine-IR neuronal processes in the rhopalium are clearly continuous with a subset of the MNN axons. This suggests that sensory input from the taurine-IR sensory cells could be transmitted into (parts of) the MNN directly and/or indirectly via the marginal center.

Development of rhopalia is an ordered process

Our anatomical observations indicate that the rhopalial nervous system in Aurelia sp. 1 develops in an ordered manner (Fig. 8). In early developing ephyrae within the strobila (the "prephyra I" stage), lithocysts and a small number of neurons, including those belonging to aborallateral and oral-proximal groups, begin differentiation in rhopalia, and the DNN is already widespread in exum- 


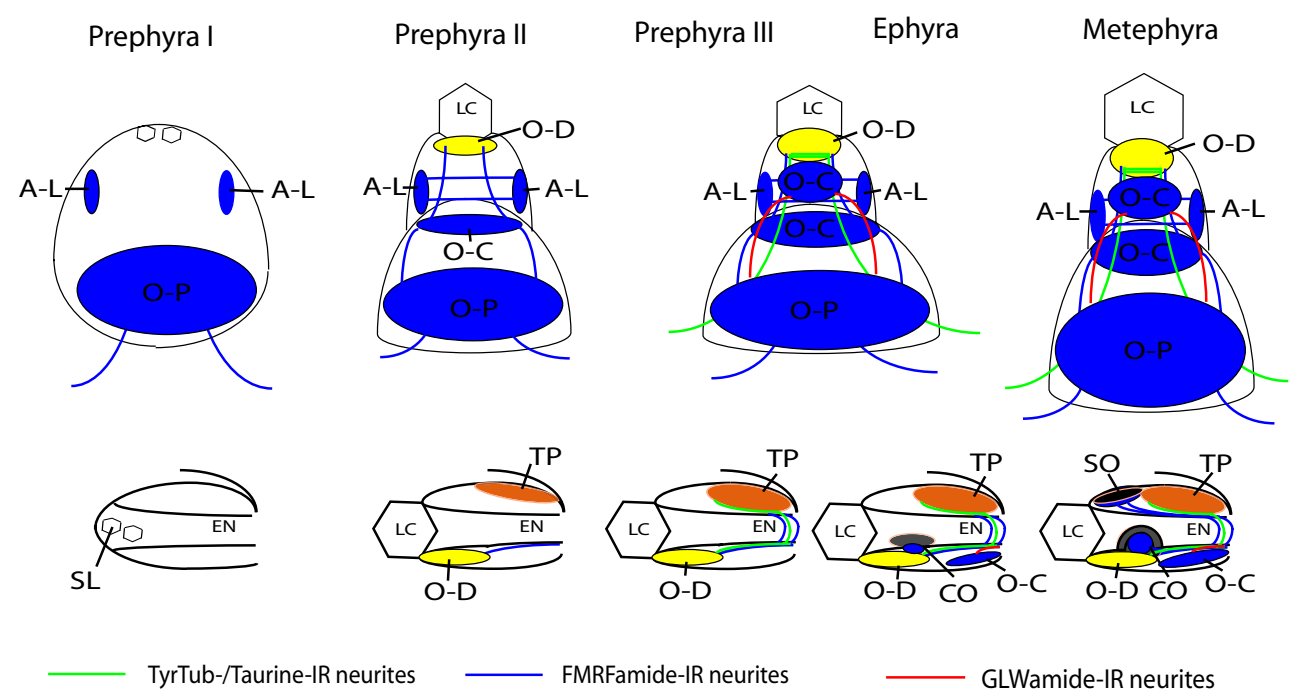

Fig. 8 Schematic representation of rhopalial development from the prephyra I to the metephyra stages in Aurelia sp. 1. Upper row is oral view, and lower row is lateral view of the rhopalium. Prephyra I: statoliths, aboral-lateral and oral-proximal groups of neurons differentiate. Prephyra II: oral-distal, oral-central groups of neurons, as well as phalloidin-positive rings in areas of the future touch plate and the oral-distal group begin to develop. Prephyra III: tyrTub-/taurine-IR axons make connections with the MNN, and strong Taurineimmunoreactivity occurs in the touch plate cells, as well as in the oral-distal sensory cells. Ephyra: pigment-cup ocellus develops. Metephyra: pigment-spot ocellus develops. $S L$ statolith, $L C$ lithocyst, $E N$ endoderm, $O-D$ oral-distal group, $A-L$ aboral-lateral group, $O-C$ oral-central group, $O-P$ oral-proximal group, $S O$ spot-ocellus, $T P$ touch plate, $C O$ cup-ocellus brellar and subumbrellar ectoderm. During the prephyra II stage, more neurons are born and differentiate, shown by of the appearance of microvilli/stereocilia in the region of the future touch plate, aboral-lateral and oral-distal groups of sensory cells. The oral-central group of sensory cells also appears at this stage. Thus, development of the presumptive gravity-sensing organ of the rhopalium, consisting of the lithocyst and the touch plate, begins early. During the prephyra III stage, a network of thick tyrTub-IR neurites forms, projecting away from the rhopalium at the base laterally to join the developing $\mathrm{MNN}$, and this coincides with the onset of coordinated muscular contractions (the "prephyra III" stage); the pacemaker function of the marginal center is established. At the free-swimming "ephyra" stage, the pigment-cup ocellus begins differentiation. At the late ephyra (metephyra) stage, the pigment-cup ocellus becomes cup-shaped, presumably via invagination (Yamasu and Yoshida 1973), and the pigment-spot ocellus develops.

Development of presumptive mechanoreceptors

Upon electron microscopic examination of development of the touch plate, Spangenberg $(1991,1996)$ asserted that an "organized" touch plate did not form until long (48 h) after the liberation of ephyrae from a strobila in Aurelia. However, our data show that enrichment of microvilli/ stereocilia begins in the aboral ectoderm of the intermediate segment (i.e., future touch plate region) by the prephyra II stage, and strong taurine-like immunoreactivity is observed in the same region at the prephyra III stage, suggesting that major aspects of touch-plate differentiation occur earlier, during strobilation. By the last prephyra stage (III), lithocysts have enlarged, and numerous microvilli/stereocilia, similar in density to those in the touch plate in the adult, are found in the future touch plate region on the aboral ectoderm of the intermediate region, in close contact with the overlying subumbrellar epithelium. The occurrence of a field of epidermal sensory cells, including the taurineIR sensory cells, with pronounced microvilli/stereocilia in the touch plate region of the rhopalium of some of the more developed ephyrae in a strobila, suggests the presence of touch plate function, potentially in gravity sensation, prior to the final differentiation of the touch plate structure.

We identified a cluster of touch-plate-cell-like epidermal sensory cells in the intermediate segment close to the lithocyst on the oral side of the rhopalium, which we classified as the oral-distal group. Resembling the touch plate, this group contains strongly taurine-IR cells with pronounced microvilli/stereocilia at the apical cell surface surrounding the base of knobbed cilia. In addition, coordinated bending of a cilium and associated stereocilia - a phenomenon previously only known from a subset of touch plate cells in Aurelia (Spangenberg et al. 1996) -was observed in a presumptive oral-distal sensory cell. Interestingly, the oral-distal group and the touch plate display a similar pattern of development as well; microvilli/stereocilia differentiate at the prephyra II stage, and strong taurine-like 
expression appears at the prephyra III stage. Thus, the oraldistal group of sensory cells constitutes a structure with similar morphological, molecular, and developmental characteristics to the touch plate. On the basis of these parallels, it could be speculated that this structure may also be touchplate-like in function; the oral-distal group of sensory cells may constitute another mechanosensory organ of the rhopalium.

As the rhopalium grows, the oral-distal sensory cells continue to increase in number and occupy the terminal region of the rhopalium in adult (Supplementary Fig. 1, C, C'). These sensory cells could be sensitive to local bending or stretching of the epithelium that might occur in this region due to the weight of the lithocyst upon tilting of the medusa, aiding in the gravity-sensing function of rhopalia. In addition, stimulus could occur via contact with (food) particles in the water column, which could facilitate the feeding or escape response in ephyrae by eliciting the contraction of the rhopalar arms. The function(s) of the newly identified putative mechanosensory structure, as well as of the touch plate and the pigment-spot ocellus (see below), will need to be experimentally verified in future studies.

\section{Anatomical location of the "marginal center"}

Removal of all rhopalia in Aurelia causes cessation of the swimming contraction, but one rhopalium is sufficient to restore the activity (Romanes 1885), suggesting that rhopalia act as pacemakers for regular swimming contractions. The region of pacemaker activity that generates periodic electrical impulses into the MNN to control swimming contraction is called the "marginal center" (Passano 1982). The exact anatomical location of the marginal center is, however, unclear. Passano (1973) claimed that pacemaker output was observed from the rhopalia whose "outer half" was excised, suggesting that the pacemaker may reside in the "inner" half of the rhopalium. In addition, the marginal center likely receives neuronal input from the sensory system of the rhopalia (as discussed above), as well as from the DNN, and sends output via the MNN (reviewed in Lesh-Laurie and Suchy 1991). Thus, the marginal center must be able to communicate with neurons originating from these surrounding nervous systems. Our data show that neuronal connections between the rhopalial nervous system and the MNN develop via lateral projection of tyrTub-IR axons away from the base of the rhopalium (prephyra III), and this is correlated with the onset of the pacemaker activity (i.e., swimming contractions) of the marginal center. This reasoning constrains the marginal center to the cells in the basal region of the rhopalium (e.g., oral-proximal neurons) that can communicate with the DNN, as well as with the sensory cells in the rhopalia, and also generate regular electrical impulses into the MNN via the tyrTub-IR axons at the base of the rhopalium.

Structure, function, and development of the ocelli

As described, development of presumptive photoreceptors occurs after liberation of ephyrae from strobilae. Differentiation of the pigment-cup ocellus has been correlated with the development of behavioral responses to light stimuli (Yoshida and Yoshino 1980). In addition, intramembranous particles (IMPs; presumed to represent the photosensory proteins, rhodopsins) of the microvillar and ciliary membranes of the sensory cells of the pigment-cup ocellus, revealed by the freeze fracture technique, were similar in size and density to IMPs in photoreceptive membranes of differentiated photoreceptor cells of Bilateria (Takasu and Yoshida 1984). Thus, sensory cells in the pigment-cup ocellus are likely to be photosensitive. In contrast, the size and density of IMPs in the microvillar and ciliary membranes of ectodermal pigment cells in the pigmentspot ocellus do not resemble those from known photoreceptor cells, suggesting that they may not be photosensory (Takasu and Yoshida 1984). However, these pigmented cells show FMRFamide-like expression with neurites extending at the base and have long cilia (up to $50 \mu \mathrm{m}$ ) with bulbous tips forming likely apical sensory apparatuses. This strongly indicates that the pigment-spot ocellus contains cells that are sensory if not photo-sensory. A mass of knobbed, long cilia in the space created by the depression of the pigment-spot epithelium might be effective in sensing the chemical environment if a water flow can be circulated in the depression (perhaps by ciliary action). The formation of depression of sensory epithelium, often called the sensory pit, is a typical structure of chemosensory organs in marine invertebrates (Brusca and Brusca 2003); the pigment-spot "ocellus" could potentially act as a chemosensory organ.

\section{Evolutionary considerations}

Homology of scyphozoan rhopalia with staurozoan rhopalioids and cubozoan rhopalia is inferred based largely on the position and ontogenetic origin. They are arranged in the perradial and interradial positions at the bell margin and are derived ontogenetically from polyp tentacles (Thiel 1966). The most recent molecular phylogenetic study suggests that the phylogenetic relationship among cnidarians is [Anthozoa, (Staurozoa, (Hydrozoa, (Scyphozoa, Cubozoa)))] (Collins et al. 2006). If this is the case, the last common ancestor of Medusozoa likely had rhopalioid/ rhopalium-like structures presumably derived from the polyp tentacles in the perradial and interradial positions. This raises the possibility that hydrozoan marginal sensory 
structures, including statocysts, ocelli, and the "tentacular ganglia" located at the base of the tentacles in medusae (Mackie 1971), may also be related to the rhopalioid/ rhopalium, despite structural differences and the potential independent evolutionary origin of medusae in Hydrozoa (Marques and Collins 2004; Thiel 1966; but see Jacobs and Gates 2003 for consideration of the likelihood of evolutionary loss of medusae). Indeed, statocysts of some hydrozoans are ontogenetically derived from polyp tentacles, and statoliths are generally of endodermal origin as in other cnidarians (Horridge 1969; Marques and Collins 2004). In addition, an independent origin of hydrozoan medusae does not necessitate that characters in hydrozoan medusae are also independently derived; they could have evolved prior to the origin of hydrozoan medusae (cf. Collins et al. 2006). Finally, expression of homologous sequences related to bilaterian genes involved in sensory organ development (e.g., Six and Pax families) occurs in the sensory structures (i.e., eyes and tentacle bulbs) of hydrozoans (Groger et al. 2000; Stierwald et al. 2004) as well as cubozoan and scyphozoan rhopalia (Bebenek et al. 2004; Kozmik et al. 2003). This may suggest a possible evolutionary kinship not only among hydrozoan and scyphozoan/cubozoan sensory structures but also among cnidarian and bilaterian sensory structures (Jacobs et al. 2007).

Morphologically, there is a high degree of modification among rhopalia/rhopalioids as well. For example, cubozoan rhopalia contain two pairs of laterally located ocelli on the aboral side of the rhopalium (Skogh et al. 2006), which do not have clearly homologous counterparts in scyphozoan rhopalia. We do note, however, that RFamide immunoreactivity has been observed in cells in one of the pairs (slit eyes) (Martin 2004), and they are similar in position to the FMRFamide-IR aboral-lateral sensory cells identified in this study. Similarities in position and the immunohistochemical characteristic suggest potential homology between the slit eyes of cubozoan rhopalia and the aboral-lateral group of sensory cells in scyphozoan rhopalia. Among scyphozoan rhopalia, there is also a high degree of structural differences (Arai 1997; Russell 1970); for instance, Paraphyllina intermedia have a spherical lens in the ocellus on the oral side of the rhopalium (Maas 1903), while other species may completely lack ocelli. Staurozoan rhopalioids are also morphologically diverse; their forms range from simple tentacle-like projections to thickened, horseshoe-shaped tissues, called "anchors" or "colletocystophores," consisting of elongated ectodermal cells that include sensory and secretory cells (Berrill 1962; Hyman 1940). Comparative data on the development of staurozoan rhopalioids, rhopalia from cubozoans and other scyphozoans, and marginal sensory structures from hydrozoans from a diverse range of species should help not only to clarify the relationship among these sensory structures but also to identify the developmental processes responsible for the evolution of morphologically divergent sensory structures in Cnidaria.

Acknowledgements We thank Mike Schaadt and Kiersten Darrow of the Cabrillo Marine aquarium, San Pedro, CA, for providing us with the Aurelia material, and Dr. Thomas Leitz for providing us with the anti-GLWamide antibody. We also thank an anonymous reviewer for helpful comments on the earlier version of the manuscript. This work was supported by the UCLA Edwin W. Pauley fellowship (to N.N.) and the NASA Astrobiology Institute.

Open Access This article is distributed under the terms of the Creative Commons Attribution Noncommercial License which permits any noncommercial use, distribution, and reproduction in any medium, provided the original author(s) and source are credited.

\section{References}

Anderson PAV, Schwab WE (1981) The organization and structure of nerve and muscle in the jellyfish Cyanea-Capillata (Coelenterata, Scyphozoa). J Morphol 170:383-399

Anderson PAV, Thompson LF, Moneypenny CG (2004) Evidence for a common pattern of peptidergic innervation of cnidocytes. Biol Bull 207:141-146

Arai MN (1997) A functional biology of Scyphozoa. Chapman \& Hall, London

Bebenek IG, Gates RD, Morris J, Hartenstein V, Jacobs DK (2004) Sine oculis in basal Metazoa. Dev Genes Evol 214:342-351

Berrill M (1962) Biology of 3 New England Stauromedusae, with a description of a new species. Can J Zool 40:1249

Bozler E (1926) Sinnes- und Nevenphysiologische Untersuchungen an Scyphomedusen. Zeitschrift für vergleichende Physiologie 4:37-80

Brusca RC, Brusca GJ (2003) Invertebrates. Sinauer, MA

Carlberg M, Alfredsson K, Nielsen SO, Anderson PAV (1995) Taurine-like immunoreactivity in the motor-nerve net of the jellyfish Cyanea-Capillata. Biol Bull 188:78-82

Chapman DM, James R (1973) Intraepithelial flagella in the medusa of Aurelia aurita (L.). Publ Seto Mar Biol Lab 20:731-743

Chia FS, Amerongen HM, Peteya DJ (1984) Ultrastructure of the neuromuscular system of the polyp of Aurelia aurita L, 1758 (Cnidaria, Scyphozoa). J Morphol 180:69-79

Collins AG (2002) Phylogeny of Medusozoa and the evolution of cnidarian life cycles. J Evol Biol 15:418-432

Collins AG, Schuchert P, Marques AC, Jankowski T, Medina M, Schierwater B (2006) Medusozoan phylogeny and character evolution clarified by new large and small subunit rDNA data and an assessment of the utility of phylogenetic mixture models. Syst Biol 55:97-115

Dawson MN, Jacobs DK (2001) Molecular evidence for cryptic species of Aurelia aurita (Cnidaria, Scyphozoa). Biol Bull 200:92-96

Frankel G (1925) Der statische Sinn der Medusen. Z Vergl Physiol 2:658-690

Groger H, Callaerts P, Gehring WJ, Schmid V (2000) Characterization and expression analysis of an ancestor-type Pax gene in the hydrozoan jellyfish Podocoryne carnea. Mech Dev 94:157-169

Horridge GA (1954) The nerves and muscles of medusae.1. Conduction in the nervous system of Aurelia aurita Lamarck. J Exp Biol 31:594-600

Horridge A (1956a) The nervous system of the ephyra larva of Aurelia aurita. Q J Microsc Sci 97:59-74

Horridge GA (1956b) The nerves and muscles of medusae.5. Double innervation in scyphozoa. J Exp Biol 33:366-383 
Horridge GA (1959) The nerves and muscles of medusae.6. The rhythm. J Exp Biol 36:72-91

Horridge GA (1969) Statocysts of medusae and evolution of stereocilia. Tissue Cell 1:341-353

Horstmann E (1934) Untersuchungen zur physiologie der schwimmbewegung der scyphomedusen. Pflugers Arch Ges Physiol 234:406-420

Hundgen M, Biela C (1982) Fine structure of touch-plates in the scyphomedusan Aurelia aurita. J Ultrastruct Res 80:178-184

Hyman LH (1940) The invertebrates: protozoa through ctenophora. McGraw-Hill, New York

Jacobs DK, Gates RD (2003) Developmental genes and the reconstruction of metazoan evolution-implications of evolutionary loss, limits on inference of ancestry and type 2 errors. Integr Comp Biol 43:11-18

Jacobs DK, Nakanishi N, Yuan D, Camara A, Nichols SA, Hartenstein V (2007) Evolution of sensory structures in basal metazoa. Integr Comp Biol 47:712-723

Kawahara M, Uye S, Ohtsu K, Iizumi H (2006) Unusual population explosion of the giant jellyfish Nemopilema nomurai (Scyphozoa: Rhizostomeae) in east Asian waters. Mar Ecol Prog Ser 307:161173

Kozmik Z, Daube M, Frei E, Norman B, Kos L, Dishaw LJ, Noll M, Piatigorsky J (2003) Role of pax genes in eye evolution: a cnidarian PaxB gene uniting Pax2 and Pax6 functions. Dev Cell 5:773-785

Lesh-Laurie GE, Suchy PE (1991) Cnidaria: Scyphozoa and Cubozoa. In: Harrison FW, Westfall JA (eds) Microscopic anatomy of the invertebrates, vol 2. Wiley-Liss, New York, pp 185-266

Maas O (1903) Die Scyphomedusen der Siboga-Expedition. SibogaExpeditie 11:1-91

Mackie GO (1971) Neurological complexity in medusae: a report of central nervous organization in Sarsia. Actas del $1^{\circ}$ Simposio Internacional de Zoofilogenia, Salmanca, Univ of Salmanca, pp 269-280

Marques AC, Collins AG (2004) Cladistic analysis of Medusozoa and cnidarian evolution. Invertebr Biol 123:23-42

Martin VJ (2002) Photoreceptors of cnidarians. Can J Zool 80:1703-1722

Martin VJ (2004) Photoreceptors of cubozoan jellyfish. Hydrobiologia 530-31:135-144

Medina M, Collins AG, Silberman JD, Sogin ML (2001) Evaluating hypotheses of basal animal phylogeny using complete sequences of large and small subunit rRNA. Proc Natl Acad Sci U S A 98:9707-9712

Nakanishi N, Yuan D, Jacobs DK, Hartenstein V (2008) Early development, pattern, and reorganization of the planula nervous system in Aurelia (Cnidaria, Scyphozoa). Dev Genes Evol 218:511-524

Passano LM (1965) Pacemakers and activity patterns in MedusaeHomage to Romanes. Am Zool 5:465

Passano LM (1973) Behavioral control systems in medusae; a comparison between hydro- and scyphomedusae. Publ Seto Mar Biol Lab 20:615-645

Passano LM (1982) Scyphozoa and Cubozoa. In: Shelton GAB (ed) Electrical conduction and behaviour in 'simple' invertebrates. Oxford University Press, New York, pp 149-202

Passano KN, Passano LM (1971) The endodermal nerve net of Scyphozoa. J Morphol 133:105-124

Plickert G, Schneider B (2004) Neuropeptides and photic behavior in Cnidaria. Hydrobiologia 530:49-57

Romanes GJ (1877) Further observations on the locomotor system of medusae. Philos Trans 167:659-752

Romanes GJ (1885) Jellyfish, starfish and sea urchins, being a research on primitive nervous systems. Appleton, New York

Russell FS (1970) The medusae of the British isles. Cambridge University Press, Cambridge
Sakaguchi M, Imai Y, Nomoto S (1999) The presence and distribution of RFamide-like immunoreactive nerve fibers in scyphistomae of Aurelia aurita. Comp Biochem Physiol Part A Mol Integr Physiol 122:261-266

Satterlie RA (2002) Neuronal control of swimming in jellyfish: a comparative story. Can J Zool 80:1654-1669

Schafer EA (1878) Observations on the nervous system of Aurelia aurita. Phil Trans Roy Soc London 169:563-575

Schierwater B, Eitel M, Jakob W, Osigus HJ, Hadrys H, Dellaporta SL, Kolokotronis SO, DeSalle R (2009) Concatenated analysis sheds light on early metazoan evolution and fuels a modern "Urmetazoon" hypothesis. PLoS Biol 7:36-44

Schmich J, Rudolf R, Trepel S, Leitz T (1998) Immunohistochemical studies of GLWamides in Cnidaria. Cell Tissue Res 294:169-177

Schwab WE (1977) Ontogeny of swimming behavior in scyphozoan, Aurelia-Aurita.1. electrophysiological analysis. Biol Bull 152:233-250

Schwab WE, Anderson PAV (1980) Intracellular-recordings of spontaneous and evoked electrical events in the motor neurons of the jellyfish, Cyanea-Capillata. Am Zool 20:941-941

Skogh C, Garm A, Nilsson DE, Ekstrom P (2006) Bilaterally symmetrical rhopalial nervous system of the box jellyfish Tripedalia cystophora. J Morphol 267:1391-1405

Spangenberg D (1976) Intracellular statolith synthesis in Aurelia aurita. In: Watabe $\mathrm{N}$, Wilbur $\mathrm{K}$ (eds) The mechanisms of mineralization in the invertebrates and plants. University of South Carolina Press, Columbia, pp 231-248

Spangenberg DB (1991) Rhopalium development in Aurelia aurita ephyrae. Hydrobiologia 216:45-49

Spangenberg DB, Kuenning W (1976) SEM studies of strobilating Aurelia. In: Mackie GO (ed) Coelenterate ecology and behavior. Plenum, New York, pp 377-386

Spangenberg D, Coccaro E, Schwarte R, Lowe B (1996) Touch-plate and statolith formation in graviceptors of ephyrae which developed while weightless in space. Scanning Microsc 10:875-888

Stierwald M, Yanze N, Bamert RP, Kammermeier L, Schmid V (2004) The Sine oculis/Six class family of homeobox genes in jellyfish with and without eyes: development and eye regeneration. Dev Biol 274:70-81

Takasu N, Yoshida M (1984) Freeze-fracture and histofluorescence studies on photoreceptive membranes of medusan ocelli. Zool Sci 1:367-374

Thiel H (1966) The evolution of scyphozoa: a review. In: Rees WJ (ed) The Cnidaria and their evolution. Academic, London, pp $77-117$

Wallberg A, Thollesson M, Farris JS, Jondelius U (2004) The phylogenetic position of the comb jellies (Ctenophora) and the importance of taxonomic sampling. Cladistics 20:558-578

Westfall JA (2004) Neural pathways and innervation of cnidocytes in tentacles of sea anemones. Hydrobiologia 530:117-121

Yamasu T, Yoshida M (1973) Electron Microscopy on the photoreceptors of an anthomedusa and a scyphomedusa. Publ Seto Mar Biol Lab 20:757-778

Yasuda T (1983) Biology of the common jelly-fish, Aurelia aurita (III): notes of the metamorphosis from ephyra to young medusa and survival rate. Aquabiology 5:302-306

Yoshida M, Yoshino Y (1980) Differentiation of ocelli in ephyrae of Aurelia aurita. In: Tardent P, Tardent R (eds) Developmental and cellular biology of coelenterates. Elsevier, Amsterdam, The Netherlands, pp 343-346

Yuan D, Nakanishi N, Jacobs DK, Hartenstein V (2008) Embryonic development and metamorphosis of the scyphozoan Aurelia (Cnidaria, Scyphozoa). Dev Genes Evol 218:525-539 